\title{
Landråd von Uslar
}

- en embedsmand i kamp med »rigsfjenderne«

\section{Af Jørgen Witte}

Rafael José Perfecto Antonio von Uslar (1853-1931) virkede som landråd i Aabenraa i årene fra 1895 til 1913. Han var en af tidens mest farverige og omstridte embedsmænd. Med alle midler bekæmpede han de farlige statsfjender - danskerne og socialdemokraterne. Han kom derved på kant med en del af sine foresatte - for den preussiske administration byggede på nøje udformede retsregler, som alle måtte følge.

Afhandlingen her fortæller om von Uslars embedsvirke. Blandt meget andet illustrerer von Uslars skæbne spændingen mellem det preussiske retssamfund og de spegede politiske hensyn i statens yderste provins mod nord.

Set med nutidige, danske øjne var landråderne, der 1867-1920 stod for ledelsen af den lokale preussiske forvaltning i Nordslesvig, nogle fremmede fugle. Mest fascinerende er måske Rafael José Perfecto Antonio von Uslar, der virkede som landråd i Aabenraa 1895-1913. Dette indtryk skyldes nok, at han var en preussisk junkertype, men af spansk-mexicansk afstamning, og at han gjorde sig bemærket ved på kejser Wilhelm IIs opfordring at søge vand med ønskekvist i Sydvestafrika 1906-08!' Så spændende disse eksotiske træk end forekommer, er det dog ikke dem, der er hovedsagen her, men hans juridiske fejder med statsfjenderne $\mathrm{i}$ hans landrådskreds, altså de dansksindede og socialdemokraterne, for at fastslå, hvordan hans forhold til disse virkelig var.

\section{Vurderingerne af landråd von Uslars virke}

Der findes to forskellige opfattelser af von Uslar. H.P.Hanssen skrev 1901 i »Haandbog i det Nordslesvigske Spørgsmaals Historie« om den dengang fungerende landråd, at von Uslar manglede den fagligt uddannede preussiske landråds forberedelse til embedet og fortrolighed med administrationen. Hans kundskaber var overfladiske, og han savnede ikke sjældent forståelse af, hvor grænserne for hans myndighed som landråd lå. Men hvad han savnede i faglig dannelse, søgte han at erstatte ved en fremtrædende iver $i$ fortyskningens tjeneste. Under Köller-politikken vakte hans ensidige, stærkt farvede indberetninger om forholdene i Aabenraa kreds gentagne gange opmærksomhed, idet Köller flittigt lod dem citere $\mathrm{i}$ parlamenterne og $\mathrm{i}$ den officiøse presse for 


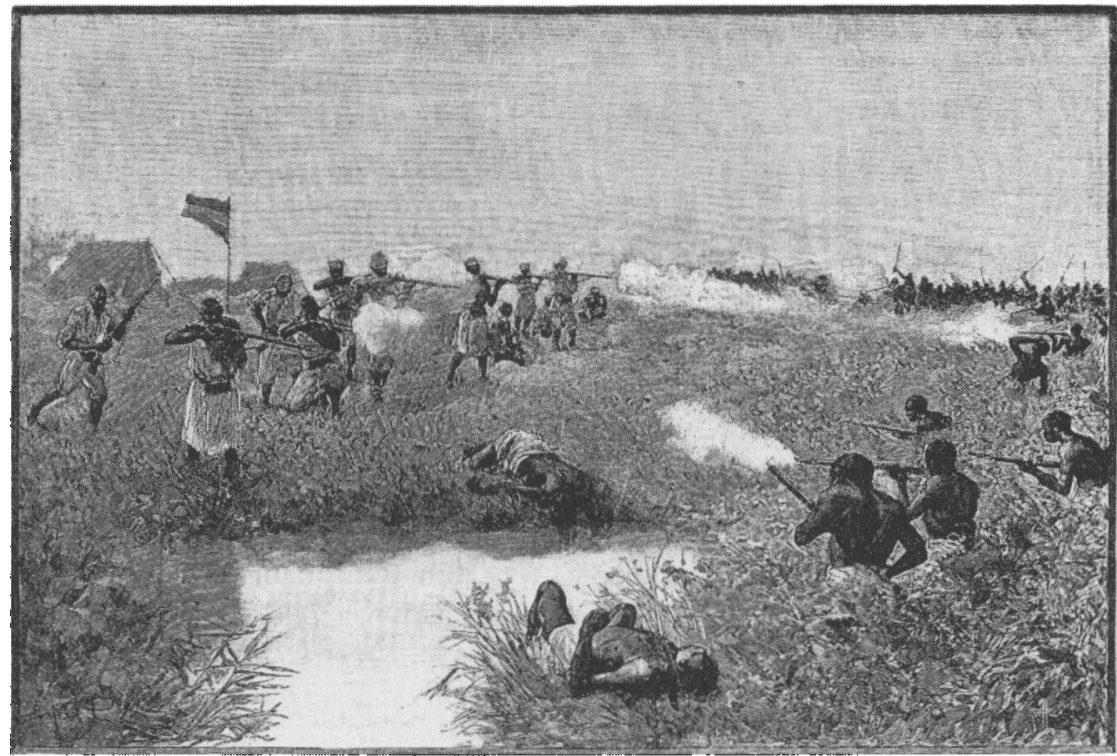

Landråd von Uslars karriere rummer et lille pust fra det tyske kolonieventyr. I drene 1906-08 besogte han det tyske protektorat Deutsch Südwestafrika, i dag Namibia. Nogle år for, i 1904, havde tyskernes udbytning af afrikanerne medfort et heftigt opror blandt det indfodte folk hereroerne, der blev nosten udryddet. Billedet viser kampe mellem tyske soldater og indfødte. (Daniel Brunn: Afrika, dets Opdagelse. Erobring og Kolonisation, Kbh. 1901, bd. II s. 224). Der lurede ogsa andre farer end de krigeriske i det torre land. En gang skal landråd von Uslar have varet doden nar. 11912 omtaler et brev til landråden fra en Eugen Michaelis episoden i en påtrangende og teatralsk tone: "... Kan De endnu huske hin dag. da motoren standsede mellem Richthofen og Rössing? Da vi to muttersalene i Namibs gledende sol slabte os mod Rössing? Husker De endnu, herr landrad, da De sagde, at De ikke kunne mere, for Deres hjerte svigtede! Da tog jeg deres arm og nasten bar Dem mojsommeligt videre, for et holdt i denne orkenens helvedesbrand havde varet det samme som doden. Og snart derpå måtte vi alligevel satte os ned, for torsten lammede vore tunger. Med hvilken glade opdagede jeg da hos mig fundet af en appelsin, og jeg gav Dem gerne nasten hele frugten og beholdt for mig selv kun et lille stykke. Styrket tog De min arm, og idet vi gik langsomt videre, sagde De ordret til mig, arede herr landråd: Herr $M$., det vil jeg aldrig glemme Dem, for jeg skylder Dem nasten mit liv ... " (Aab ldr. A spec 2. Wahl und Ernennung des Landrats ... hft. 5 1911-18).

at bevise, hvor resultatrig udvisningspolitikken $\operatorname{var}^{2}$. von Uslars politiske modstander, H.P.Hanssen, fældede således en ret så hård dom over ham ${ }^{3}$.

I de følgende år kom H.P. Hanssen enkelte gange nærmere ind på von Uslar. Han afslørede i en af sine artikler om Köller-politikken, hvordan von Uslar i 1903 strengt fortroligt havde beordret sine underordnede politimyndigheder til at fortsætte en boykot af gæstgivere, der stillede lokaler til rådighed for valgmøder med den dansksindede rigsdagskandidat, fabrikant $M$. Andresen fra Aabenraa. Samtidig dermed havde von Uslar forsikret Andresen om, at det ikke var tilfældet. H.P.Hanssen konkluderede, at landråd von Uslars 
fremgangsmåde var karakteristisk for Köller-politikken. Kun en voldspolitik, der foruden det retslige også savnede ethvert etisk grundlag, betjente sig af sådanne midler. En senere tid ville nok have sagt, at det var lumpne metoder.

Den tyske historiker Kai Detlev Sievers har vurderet von Uslar anderledes. I bogen "Die Köllerpolitik und ihr Echo in der deutschen Presse 1897-1901" (1964) skrev han, at von Uslars embedsførelse var ret mådeholden. Selv om von Uslar under Köllerpolitikken billigede de skarpe forholdsregler imod den danske agitation, så rettede hans modvilje sig dog mindre mod det danske element som sådan end mod dets løsrivelsesbestræbelser ${ }^{5}$. Han var altså ikke imod de dansksindedes væremåde, men mod en dansk irredenta.

Sievers har givet en mere omfattende karakteristik af von Uslar i det nye Schleswig-Holsteinisches Biographisches Lexikon. Her nævnes, at von Uslar gentagne gange var stedfortræder for landråd von Bonin i Aabenraa kreds, og at han efter denne énstemmigt af Aabenraa kredsdag blev foreslået som ny landråd og udnæunt dertil, selv om han ikke var juridisk uddannet. von Uslar opfattes her som en velset og dygtig amatør. Om hans konflikter skriver Sievers, at von Uslar gentagne gange kom ind i det dansk-tyske modsætningsforhold på grund af sin kreds' politisk særlig udsatte placering. Meningen er, at Aabenraa var centrum for de dansksindedes aktiviteter, og at han derfor uden egen skyld blev inddraget i den nationale konflikt. Ifølge Sievers var von Uslars embedsførelse som helhed meget modereret. Ganske vist stod han entydigt på statens side, men hans forholdsregler imod den danske agitation var uden hensynsløs skarphed, og hans embedsvirke var båret af et godt forhold til befolkningen'.

To andre historikere har beskæftiget sig med sider af von Uslars virke. Jernbanehistorikeren Birger Wilcke har fremhævet hans betydelige indsats for kredsbanerne, og han mener, at von Uslar var personlig vellidt af både danske og tyske, når man ser bort fra hans uheldige fremfærd i Köllerperioden?. Gottlieb Japsen har ikke direkte karakteriseret den farverige von Uslar, men har anført, at han ikke var så smidig og begavet som sin stedfortræder $\mathrm{i}$ perioden 1906-08, Dryander. Landråd von Uslar brød sig ikke om Den Tyske Forening eller om de Frisindede. Hans støtter i Aabenraa kreds var de konservative storbønder, af hvilke lederne fungerede som amtsforstandere (politiembedsmænd på landet) under ham. Dette landrådsparti led sit endelige nederlag 1906, da von Uslar var i Afrika. Den konstituerede landråd Dryander søgte at styrke tyskernes stilling ved et samarbejde med Den Tyske Forening i stedet for at modarbejde den ${ }^{8}$.

H.P.Hanssens og Sievers' opfattelser er ikke forenelige. Denne artikel vil i det store og hele give H.P.Hanssen ret i vurderingen. Rigsfjenderne var ikke kun de dansksindede, men også socialdemokraterne, og von Uslars konflikter 
med dem foregik på det administrative, politimæssige og retlige plan. I det følgende vil der blive berettet om nogle af de mere markante sager, som von Uslar var part i. Indledningsvis vil vi dog se lidt nærmere på hans liv og karriere i tiden før udnævnelsen til landråd.

\section{von Uslars liv og karriere til 1895}

Landråd von Uslar var født den 18. april 1853 i Mexico, hvor faderen, Adolf von Uslar, var tysk generalkonsul. Moderen hed Vincenta de Jimeno og var mexicaner af spansk afstamning. Da Rafael var fem år, flyttede familien tilbage til Tyskland, først til Frankfurt am Main, og i 1860 til Hannover. Her gik han i underskolen og på "Lyzeum « til 1865. Familien von Uslar hørte til en udbredt adelig slægt i Mellemtyskland, og på denne tid overtog faderen riddergodset Borgania i Schlesien. Rafael fik en kort tid undervisning af en huslærer, men kom så på gymnasiet i Braunschweig, hvor faderen havde købt et hus. 1871-72 gik Rafael von Uslar til forelæsninger på Collegium Carolinum i matematik, naturvidenskaber, nationaløkonomi, fransk og engelsk. Dernæst var han elev på en domæne og gennemførte sin militærtjeneste som etårsfrivillig ved Oldenburgisches Dragoner Regiment Nr. 19 1873-74. Da faderen døde, overtog Rafael von Uslar som ældste søn driften af familiegodset, Haus Rethmar i provinsen Hannover". von Uslars uddannelse kan derfor næppe karakteriseres som andet end en højere almenuddannelse med særligt kendskab til godsdrift.

Efter at have solgt faderens gods købte von Uslar i 1885 Buskmose i Rinkenæs sogn for 310.000 mark. Den var en af Nordslesvigs store gårde med et areal på 187 hektar, og von Uslar købte jord til, så den i 1904 omfattede 191 hektar og 80 hektar skov. På gården opførte han en standsmæssig villa $\mathrm{i}$ gotisk stil med to højloftede etager over en høj kælder og forsynet med et højt tårn i sydøsthjørnet. Indenfor var bygningen indrettet i en fantasifuld middelalderinspireret stil. Opførelsen fandt sted i 1880 'erne, hvor landbrugets store afsætningskrise endnu ikke var afsluttet. von Uslars ledelse af ejendommen var ikke den bedste, og måske forbyggede han sig. Hans formueforhold forringedes $\mathrm{i}$ hvert fald. Da han købte ejendommen, stod der gæld i den for 175.000 mark, svarende til $56 \%$ af købssummen. Men da den preusiske domæneforvaltning i 1905 overtog ejendommen, formentlig for at redde ham fra økonomisk ruin, udgjorde gælden 335.000 mark, hvilket var $82 \%$ af salgsprisen på 410.000 mark. Den forøgede gældssætning var sket frem til 1895, hvor von Uslar blev landråd. I 1902 flyttede han i øvrigt ind i amtmandsboligen på Brundlund slot $^{10}$. 


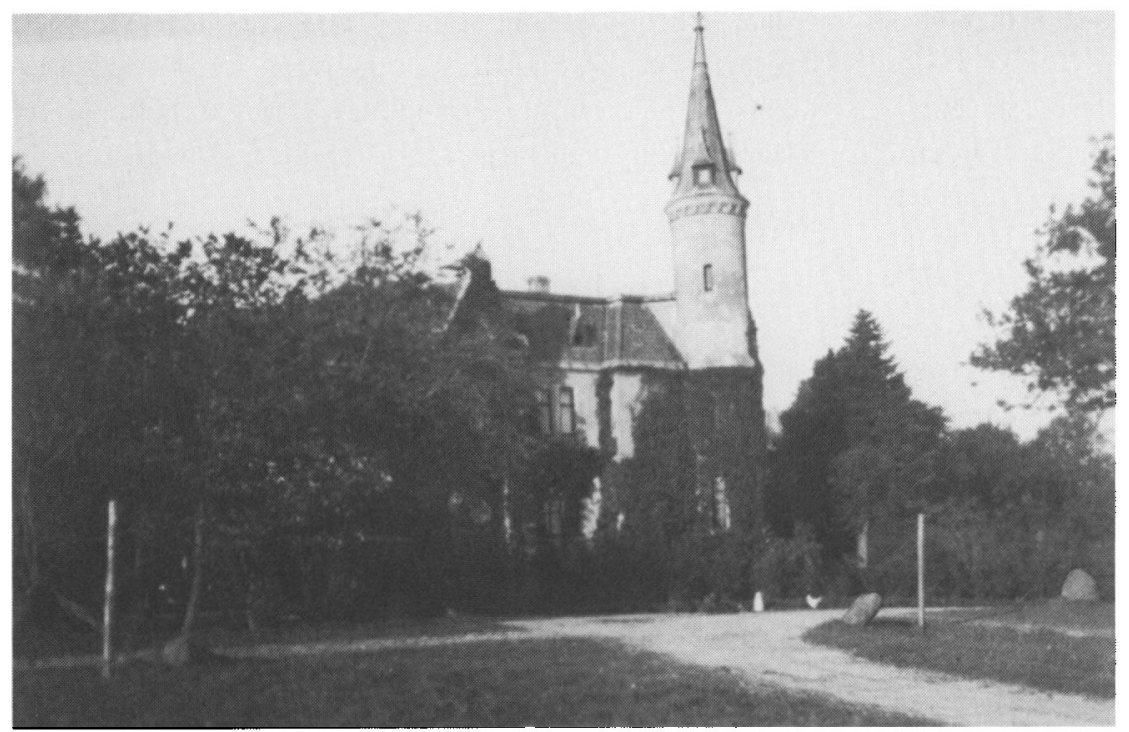

Von Uslars imposante hovedbygning pa Buskmose fotograferet ca. 1930. Spiret er senere fjernet efter en brand og erstattet af en kullet krone. Foto i Lokalhistorisk Arkiv for Gråsten by og egn.

Besiddelsen af Buskmose gav von Uslar status på egnen, og han påvirkede lokalområdet kraftigt $\mathrm{i}$ tysk retning. Omkring ham var der en tysktalende kerne, der bestod af en gartner, en kusk, en skovfoged, en amtstjener og seks arbejdere, allesammen sydfra, skrev H.V.Clausen i 1893 i en artikel om folkesproget i Sønderjylland".

Den 1.april 1889 gennemførtes den slesvig-holstenske kredsordning af 1888 , som bl.a. lod den lokale politimyndighed i landdistrikterne overgå til lægmænd, de såkaldte amtsforstandere. Der indførtes en tredelt repræsentation af kredsens befolkning, opdelt efter deres skattebetaling, i den nye kredsdag. I Nordslesvig sikrede en omhyggelig beregning af census, at der blev tysk flertal i kredsdagen. Denne forelagde en liste over kandidater som amtsforstandere for overpræsidenten for provinsen Slesvig-Holsten, og der udvalgtes naturligvis tysksindede, så vidt muligt fra godsejergruppen. De syv stemmeberettigede godsejere, der fandtes i Aabenraa kreds i slutningen af 1880 'erne, blev alle amtsforstandere. Med den position von Uslar besad som godsejer, er det ikke overraskende, at han i 1889 udnævintes til amtsforstander for »Rinkenis Amtsbezirk « ${ }^{12}$.

Amtsforstanderens vigtigste opgave var at udøve politimyndigheden i sit amtsdistrikt, hvis størrelse svarede omtrent til et par sogne. I denne funktion var han direkte underlagt landrådens tilsyn. von Uslar tog fat på opgaven 
med kraft, og det var ikke noget lille administrativt bijob, for $\mathrm{i}$ begyndelsen af 1890'erne drejede det sig årligt om knap 1500 sager, der skulle bearbejdes eller videreekspederes til de lokale kommuneforstandere. Som amtsforstander var han formand for et fælleskommunalt organ for distriktet, så både administrativt og ledelsesmæssigt må han i disse år have fået nogen erfaring ${ }^{13}$.

von Uslar fik også kendskab til landrådens arbejdsområde gennem sit medlemskab af Aabenraa kredsdag, hvor landråden var formand. Kredsdagen valgte ham som den ene af de to kredsdeputerede, der skulle fungere som landrådens stedfortrædere $\mathrm{i}$ tilfælde $\mathrm{af}$, at denne var forhindret $\mathrm{i}$ mere end fjorten dage. For kortere tidsrum varetog kredssekretæren normalt funktioner$\mathrm{ne}^{14}$. Det var dog Indenrigsministeriet i Berlin, der var øverste instans, og som afgjorde, hvem der skulle være stedfortræder i en længere periode. Der fandtes ingen forpligtelse til at bruge en kredsdeputeret, og almindeligvis udsendte Indenrigsministeriet og regeringspræsidenten i Slesvig en regeringsassessor. Dette forhold ændredes først 1901 , hvor regeringspræsidenten meddelte, at man formentlig i længere tid ikke kunne stille assessorer til rådighed under landrådernes ferie, så under disse omstændigheder ville man ikke kunne undvære hjælpen fra de kredsdeputerede' ${ }^{15}$ !

Da landråden i Aabenraa, Joachim von Bonin, i 1892 søgte om fem ugers ferie til en badekur $i$ Wiesbaden, foreslog han regeringspræsidenten, at en regeringsreferendar Könneke, der var under uddannelse til landrådstjeneste, undtagelsesvis skulle fungere $i$ hans sted. Indenrigsministeren i Berlin kunne ikke godtage denne løsning, men ønskede i stedet den kredsdeputerede von Uslar. Åbenbart forstod Bonin godt dette vink, for de følgende gange foreslog han selv von Uslar som sin stedfortræder ${ }^{16}$.

I 1894 søgte Bonin bort fra Aabenraa, og von Uslar blev udset til at være hans efterfølger. Det er ikke muligt ud fra det lokale kildemateriale at se, hvem der stod bag denne afgørelse, men et brev fra regeringspræsidentens kontor til von Uslar antyder, hvad der er foregået. Det nævnes heri, at det var med baggrund i en henstilling fra Indenrigsministeriet, at man ønskede, at Aabenraa kredsdag kom med et forslag til genbesættelse af landrådsstillingen. Regeringspræsidenten opfordrede von Uslar til at lade forhandlingen om genbesættelsen af stillingen foregå under ledelse af den anden kredsdeputerede $^{17}$. von Uslar havde således både $\mathrm{i}$ spørgsmålet om en stedfortræder for landråden og ved selve ansættelsen som landråd sine støtter i Berlin med indflydelse på Indenrigsministeriet. I Aabenraa anbefalede så den sikre kerne af tysksindede i kredsudvalget over for kredsdagen, at man skulle foreslå von Uslar, og det skete enstemmigt ${ }^{18}$.

Det var usædvanligt, at en ikke-jurist og ikke-administrativt uddannet person blev udnævnt til landråd. En person, der var berettiget til at indtræde i 
den højere forvaltnings eller retsvæsenets tjeneste, kunne blive landråd, men kredsforordningen for Slesvig-Holsten af 1888 nævnte også en anden mulighed. En person, der i mindst et år havde boet $\mathrm{i}$ kredsen eller haft jordbesiddelse der, og som enten havde været referendar ved en domstol eller ved en forvaltningsmyndighed i mindst fire år, eller forestået et såkaldt 'selvforvaltningsembede' i samme periode, var ligeledes egnet som kandidat til et landrådsembede. Amtsforstanderposten var et sådant selvforvaltningsembede. Fra Nordslesvig kendes vist kun ét andet eksempel på en ikke-fagligt uddannet landråd, nemlig von Uslars kollega i Sønderborg, von Tschirschnitz, der var militært uddannet og konstitueret landråd i flere år, før han blev udnævnt ${ }^{19}$.

\section{von Uslars første år som landråd 1895-98}

Den preussiske landråd indtog en overmåde central placering i det administrative system. Han stod direkte under regeringspræsidenten og med stadig kontakt til denne, og hans embede omfattede alle de grene af den lokale administration, der ikke var overdraget særlige embedsmænd. I sin egenskab af statsligt forvaltningsorgan havde han opsynet med landkommunerne, militærudskrivningsvæsen, skattevæsen m.m., og han skulle overvåge den samlede politiforvaltning i kredsen. Han havde ligeledes en selvstændig politifunktion med hensyn til chausseer, jagtforhold, tyendeforhold, smitsomme sygdomme m.m. Ved siden af de statslige opgaver havde landråden også kommunale. Han var født formand for kredsdagen og kredsudvalget, der bestod af seks mænd valgt af kredsdagen. Det forvaltede de kredskommunale anliggender, bl.a. vedrørende valg af kommuneforstandere, vejvæsenet, fattigvæsenet, spiritusbevillinger osv. ${ }^{20}$.

De nordslesvigske landråder havde indflydelse på mange områder, og det var naturligt for dem, at der ikke var tale om en neutral administration, men at den preussiske stats indflydelse skulle befæstes derigennem. Selv om der var gået en menneskealder siden Danmark havde afstået området, fandtes der dog stadig et nationalt røre, som den preusiske administration imidlertid tilskrev nogle forholdsvis få agitatorer. Landråden måtte holde øje med og undertrykke mrigsfjender" som den danske bevægelse, socialdemokrater og anarkister. De nordslesvigske landråder var sikkert ret enige om dette mål, men der var væsentlige forskelle i den måde, de udførte opgaven pån.

Det gjaldt i hvert fald von Bonin og von Uslar. Den førstnæunte skrev: "... Enhver handling, selv om den er nok så uvæsentlig, må betragtes ud fra det synspunkt, om den fremmer tyskheden, og indrette den derefter, - at tale og skrive om dette må imidlertid så vidt muligt undgås. Denne arbejdsmåde er 
unægtelig møjsommelig og kan ikke opvise iøjnefaldende resultater ${ }^{22}$. Der kan således ikke være tvivl om von Bonins indstilling, men alligevel gav den dansksindede N.H.Callesen ham i 1901 den karakteristik, at han var en nobel personlighed, fornem i væsen og tænkemåde ${ }^{23}$. Denne vurdering står $\mathrm{i}$ klar modsætning til, hvad H.P. Hanssen udtrykte om von Uslar.

Forklaringen på den negative holdning til von Uslar kunne ligge deri, at den hårde konfrontationsperiode under overpræsident Mathias von Köller fandt sted under hans embedsperiode som landråd. I et års tid efter at von Köller i 1897 havde overtaget ledelsen af provinsen Slesvig-Holsten fortsatte den hidtidige politiske linje, men derefter kom den kendte Köller-politik. Denne politik havde to sider, dels et helt system af velovervejede antidanske chikaner, hvor man gik helt til lovens grænse og endda derudover, og dels i finansielle bevillinger til fremme af tyskheden i Nordslesvig. Köller-politikkens første og alment kendte side bestod af en slags terror imod de dansksindede, der blev ramt af myndighedernes udvisninger af deres sagesløse kongerigske tyende, ved angreb på deres forældreret o.m.m.. von Uslar selv gjorde sig berygtet ved en politianordning af 24 .juli $1899 \mathrm{om}$, at ingen måtte antage skolepligtige børn i tjeneste uden politiets tilladelse. Formålet med denne "Tjenestedrengekrig«, som den kaldtes fra dansksindet side, var at gøre det umuligt for dansksindede bønder at fæste hyrdedrenge. Overforvaltningsretten endte dog med at omstøde von Uslars anordning. Bestanddelene i hele Köllerpolitikken var blevet planlagt på en konference, som de nordslesvigske landråder under forsæde af overpræsidenten havde holdt i Gråsten den 29. september 1898. von Köller styrede provinsen indtil august 1901, hvorefter der under efterfølgeren Kurt von Wilmowski kom en mere lempelig praktisering af den hidtidige »faste hånds politik « ${ }^{24}$.

Det fremgår dog af landrådsarkivet, at von Uslar allerede før von Köllers tiltræden ønskede en hårdere linje over for de dansksindede. Fra sine underordnede fik han indberetninger om demonstrationer eller nålestik fra dansk side. Lige som i von Bonins tid skete der bl.a. "attentater« imod flagstænger og -snore ved skolerne i tiden omkring kejserens fødselsdag den 27.januar og ved Sedan-festen den 1.september. De dansksindede brugte Dannebrog til at markere deres holdning, og de demonstrerede også deres solidaritet med Danmark ved at sende besegsdelegationer til dette naboland eller ved at modtage besøg derfra.

Fra 1895 synes von Uslar at vare gået $\mathrm{i}$ offensiven. Han havde således af aviserne set, at borgmester Todsen i Flensborg havde forbudt de handlendes fremlæggelse af bøger med Dannebrog og tilsvarende emblemer. Landråden bad om at få anordningen og sendte den til politimesteren i Aabenraa, hvorefter denne greb ind over for boghandler Sørensens Vejkort over Sønderjyl- 
Landråd von Ulslar fotograferet omkring 1900. Historiske Samlinger.

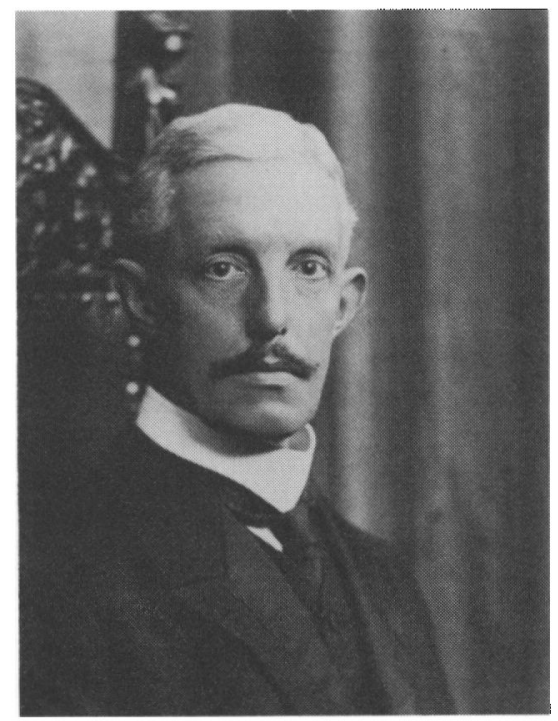

land. I en anden sag af denne art havde høker Jørgensen i Tombøl udstillet porcelænsservice dekoreret med Dannebrog $\mathrm{i}$ sin forretning, så det kunne ses af de forbipasserende. Høkeren var ved amtsretten i Aabenraa blevet dømt for "grober Unfug«, men blev frikendt ved landsretten i Flensborg. I stedet for at akceptere rettens afgørelse søgte von Uslar at bevirke en opstramning af retsgrundlaget. Det var en karakteristisk reaktion fra hans side, som det også vil ses af de senere sager. Til regeringspræsidenten skrev han, at "... følgen vil nu være, at alle de dansksindede købmænds butikker bliver udsmykket med Dannebrog ... jeg må overlade det til Deres Højærværdigheds velvillige skøn, om det ville være at anbefale at ændre den pågældende politiforordning, så det bliver forbudt offentligt at udstille Dannebrog...«. Det skal tilføjes, at det af domsudskriften med rimelig sikkerhed fremgår, at høkeren faktisk var endt ganske uskyldig $\mathrm{i}$ denne situation, $\mathrm{og}$ at landråden overreagerede. Omtrent på samme tid i slutningen af 1895 sendte von Uslar et eksemplar af Illustreret Børneblad for Nordslesvig til regeringen i Slesvig med anmodning om, at der måtte blive rejst sag mod udgiveren Mathias Andresen i Aabenraa. Landråden havde dog fejlvurderet situationen, for regeringen meddelte ham, at artiklen ikke gav anledning til at skride ind ${ }^{25}$.

I 1896 begyndte von Uslar at interessere sig mere for de danske foreninger. Han bad således sit landrådskontor anlægge et særligt akthæfte for hver enkelt dansk forening ${ }^{26}$. Samme år skete det, at amtsforstander Andresen i Hovslund hørte, at der ville blive dannet en sangforening, hvorfor han spurgte von Uslar, om den skulle overvåges $i$ henhold til foreningsloven af 1850 . Dens 
restriktive bestemmelser gik bl.a. ud på, at forsamlinger, der ville drøfte offentlige anliggender, $\mathrm{i}$ forvejen skulle anmeldes til politiet, som så ville overvåge forsamlingen. Kvinder måtte ikke deltage i foreninger, der havde til formål at diskutere politiske spørgsmål. Landråden spurgte straks, om foreningen ville blive grundlagt af førere for det danske parti, og om dansksindede blev medlemmer. Derpå svarede han amtsforstanderen, "... da foreningen særlig vil komme til at bestå af medlemmer fra det danske protestparti, så er dermed allerede givet grund til den antagelse, at den er grundlagt for at bevare danske sympatier ved at dyrke den danske sang, sådan som det gerne er blevet anbefalet af [Gustav] Johannsen, og dermed en "politisk forening". Love og medlemslister må straks indleveres. Sker dette af sig selv, så meget desto bedre. Det vil så være tvivlsomt, om kvinder kan gives adgang ...«. En forholdsvis harmløs sangforening skulle altså rammes ved en noget tvivlsom analogislutning. Foreningen blev dog ikke til noget ${ }^{27}$.

I det små viser disse eksempler, at von Uslar allerede før Köller-perioden aktivt gik ind for at undertrykke "rigsfjenderne" med administrative midler. Efter konferencen i Gråsten den 29. september 1898 med overpræsident von Köller og de nordslesvigske landrådskolleger om de skærpede forholdsregler over for de dansksindede gav von Uslar i sine næste kvartalsindberetninger til regeringen i Slesvig udtryk for, at denne politik virkede. Han skrev bl.a. "... ved de skærpede forholdsregler imod det danske protestparti er stemningen hos dets medlemmer for tiden meget trykket, selv om protestbladet Hejmdal ikke er ophørt med sine hetzartikler. De skærpede forholdsregler har indtil $\mathrm{nu}$ ført til det gode, at foredragsforeningernes forsamlinger hidtil er ophørt. ${ }^{28}$ Der er ingen tvivl om, at det var en politik, som han kunne gå ind for.

von Uslar kunne sikkert finde paralleller imellem behandlingen af Socialdemokratiet og de dansksindede. Partiets virksomhed var ganske legal fra 1890 , men opfattedes stadig af myndighederne som samfundsfarlig. Indenrigsministeren i Berlin havde i 1890 meddelt alle lokale myndigheder, at det i den nye situation var nødvendigt at imødegå de socialdemokratiske »udskejelser « med bestemthed. Til dette formål måtte politimyndighederne gøre brug af alle til rådighed stående midler under omhyggelig overholdelse af lovens rammer, men indenfor denne til grænsen af det tilladelige. De socialdemokratiske forsamlinger skulle nøje overvåges for at finde frem til strafbare udtalelser, og eventuelt kunne de opløses. Politiet skulle nøje overvåge, at de socialdemokratiske organisationer ikke trådte $\mathrm{i}$ organisatorisk forbindelse med hinanden. Deres tryksager skulle omhyggeligt gennemgås, så forbudte skrifter kunne beslaglægges hurtigt og effektivt, og endelig skulle udviste personer, der mest var erhvervsmæssige agitatorer, overvåges, når de vendte tilbage til deres tidligere bopæl ${ }^{29}$. 
Behandlingen af klager over forvaltningen

Selv om den preussiske landråd indtog en meget magtfuld stilling i det administrative system, var der dog mulighed for, at en preussisk statsborger, også en "rigsfjende«, kunne få ret over for ham. Det kunne ske igennem et udviklet forvaltningsretligt system, der ikke kendes fra dansk ret, og som kort skal omtales her, fordi det var inden for dette, at en del af von Uslars juridiske fejder kom til at udspille sig.

Borgeren kunne angribe en forvaltningsakt, f.eks. en politianordning rettet imod ham selv, på to forskellige måder. For det første var der mulighed for den administrative besværing (»Beschwerde«), hvor sagen indbragtes for den overordnede myndighed, altså fra landråd til regeringen, videre til overpræsidenten og endelig fagministeren i Berlin. Hvis klageren ikke udtrykkelig ønskede en anden fremgangsmåde, behandledes sagen som en besværing, hvorved alle sagens sider kunne behandles, altså både om myndighedens beslutning havde været retmæssig, nødvendig og rimelig.

Den anden mulighed var at indbringe en klage (»Klage«) til selvforvaltningsdomstolene. Denne vej gik fra kredsudvalget med mulighed for indankning til distriktsudvalget (»Bezirksausschuss «) i Slesvig og til Overforvaltningsretten i Berlin som øverste instans. I kredsudvalget havde landråden forsædet, og distriktsudvalget var nedsat af regeringen. En egentlig uafhængighed fandtes snarere i Overforvaltningsretten, hvis vigtigste opgave var at sørge for, at lovene blev opfattet ensartet $i$ alle preussiske provinser. En undersøgelse af denne domstols kendelser i sagerne vedrørende de dansksindede er blevet foretaget af en tysk retshistoriker Lothar Blatt, der bekræfter, at den søgte at optræde strengt juridisk og objektivt, uagtet at heller ikke dens dommere brød sig om »den danske agitation«.

I en klagesag var det centrale en påstand om, at myndighedens afgørelse havde været retsstridig, men i øvrigt kunne en sag godt begynde med en besværing og fortsætte med en klage. Dette kaldtes en forvaltningsretstrætte (»Verwaltungsstreitverfahren«), og adskillige af von Uslars sager var netop af denne slags ${ }^{30}$.

\section{Under von Köller og tiden derefter}

\section{Kontrol med kommuneforstandernes tyskhed}

Kommuneforstanderne på landet var underordnet landråden og fungerede både som organ for statsforvaltningen og for kommunen. Ganske vist var de valgt af kommuneforsamlingen eller kommunerådet, men valget skulle stadfæstes af landråden. Da de preussiske kommuner (»Gemeinden«) gennem- 
gående var meget små, var de statslige pligter nok den funktion, der tog størstedelen af kommuneforstanderens tid.

Kommuneforstanderen skulle være preussisk statsborger og skulle aflægge ed til den preussiske konge. Han udøvede et honorært statsembede ${ }^{31}$, og von Uslar anså det derfor for en alvorlig sag, hvis kommuneforstanderen ikke var helt igennem tysk og nationalpolitisk pålidelig. Hvis de overordnede var utilfredse med kommuneforstanderen, kunne der rejses en disciplinærsag imod ham ved kredsudvalget med anvendelse af loven fra 1852 om ikke-retlige embedsmænds tjenesteforseelser, særlig dens $\S 2$. Ifølge denne kunne embedsmanden også straffes, hvis han ved sin adfærd uden for embedet havde vist sig uværdig til den tillid og agtelse, som stillingen krævede ${ }^{32}$.

Under landråd von Bonin var der i Aabenraa kreds i 1890 blevet gennemført to disciplinærsager mod kommuneforstandere. I det ene tilfælde blev kommuneforstanderen afskediget for ringeagtende bemærkninger, han offentligt havde fremsat om sit embede. Den anden sag var ret tvivlsom, og her fik kommuneforstanderen kun en irettesættelse for en nationalpolitisk klodset handlemåde i forbindelse med et rigsdagsvalg ${ }^{33}$.

I følge den tyske historiker Sievers skulle von Uslars forvaltningspraksis have været ret storsindet, da der i Aabenraa kreds fungerede ikke mindre end 25 dansksindede kommuneforstandere og personregisterførere. Han citeres for at have skrevet, at det under de lokale forhold for tiden ikke kunne undgås, at også dansksindede fik overdraget kommuneforstanderopgaver, hvis disse personer forholdt sig roligt og pligtopfyldende. I hvert fald ville en aktion på én gang mod alle dansksindede kommuneforstandere vække en opsigt, som burde undgå ${ }^{34}$. Denne udtalelse kan dog ikke tages som udtryk for specielt von Uslars mening, for den blev skrevet af regeringsassessor dr.Ziller, mens han var stedfortræder for landråden under dennes ferie fra den 19. august 1897 til den 23. marts $1898^{35}$.

Baggrunden for dr.Zillers udtalelse var følgende. Ved årsskiftet 1897/98 var det rygte nået frem til regeringspræsident Zimmermann, at der i Nordslesvig fandtes kommuneforstandere og personregisterførere, der ikke blot var kendt for at være dansksindede, men som ligefrem åbent agiterede for danske foreninger. Kommuneforstander Petersen og personregisterfører Eskildsen fra Nybøl kommune, Aabenraa kreds, nævntes som de eneste ved navn. De skulle efter sigende ved kredsdagsvalget kort forinden have afgivet deres stemme til fordel for en dansk kandidat. Regeringspræsidenten afkrævede nu de nordslesvigske landråder en udtalelse om forholdene $i$ deres kredse.

Dr.Ziller kunne meddele, at der blandt kommuneforstanderne i Aabenraa kreds var yderligere fire (i Rise, Raved, Hjolderup og Bjolderup kommuner), der tidligere havde været medlem af Vælgerforeningen eller en dansk foredrags- 
Ernst Matthias von Köller, overprasident i Slesvig-Holsten 1897 1901. Historiske Samlinger.

forening, samt 20 kommuneforstandere, der kun betegnedes som dansksindede. Da der var 87 kommuneforstandere i kredsen, var det ikke nogen stor andel. Dr.Ziller agtede at afsætte Petersen, og denne nedlagde også sit hverv den 12. marts 1898 uden komplikationer. Over for de fire andre kommuneforstandere ville dr.Ziller derimod gå moderat frem og nøjes med at pålægge dem at holde sig væk fra danske foreninger. Selv om regeringspræsidenten pressede på for at få tysksindede afløsere for de fire, holdt dr.Ziller igen, sikkert også fordi der var praktiske vanskeligheder i disse kommuner med at finde nogen blandt de fåtallige tysksindede, der ville påtage sig hvervet.

Denne vanskelighed måtte også von Uslar bøje sig for, da han vendte tilbage i marts 1898 og fortsatte sagen. Alligevel kan der spores en gradsforskel i dr. Zillers og von Uslars holdning. Efter meddelelse fra den lokale amtsforstander i Bjolderup havde dr.Ziller skrevet til regeringspræsidenten og overbevist ham om, at det ikke foreløbig var muligt at skaffe en tysksindet afløser for kommuneforstander Fries i Bjolderup. von Uslar indberettede derimod allerede en måneds tid senere, at han havde skaffet en. Det drejede sig om den eneste mulige, en gæstgiver der var tilflyttet året før, og som i en kort tid havde demonstreret et tysk sindelag. Kommunerådet ville i øvrigt ikke have den tysksindede, men Fries. Da von Uslar og kredsudvalget nægtede at stadfæste valget af denne, måtte man dog bide i det sure able og vælge den tysksindede som kommuneforstander. von Uslars fremtrædende iver i fortyskningens tjeneste synes klar nok ${ }^{36}$. 
Når tysksindede kommuneforstandere viste nogen forståelse for dansk sprog og kultur, reagerede von Uslar kraftigt, som det fremgår af to tilfæelde, hvor kommuneforstanderes børn gik i skole i kongeriget for at lære dansk. Landrådens holdning var, at dette var forræderi imod den tyske sag og uantageligt. Det hører dog med til baggrunden for reaktionen, at det var en torn i øjet på de nordslesvigske landråder og von Köller, at danskheden i Nordslesvig fandt styrke ved ungdommens skolebesøg i kongeriget, og i Sønderborg kreds søgte landråd von Tschirschnitz i december 1898 ligefrem at terrorisere forældrene til at hjemtage børnene ${ }^{37}$.

Overvagtmester Conrad skrev den 15.maj $1898 \mathrm{i}$ en indberetning til von Uslar, at den tidligere kommuneforstander $\mathrm{i}$ Kværs, gårdejer Hinrichsen, der var tysksindet, havde sendt sin ældste datter af første ægteskab på en husholdningsskole i Danmark. Landråden anmodede gennem vagtmesteren Hinrichsen om ved lejlighed at komme til en samtale på Brundlund slot. Det skete to måneder senere, men samtalens indhold er desværre ikke oplyst. Dermed synes sagen at være sluttet ${ }^{38}$.

Værre var det, da en kommuneforstander $\mathrm{i}$ funktion to år senere begik samme "forseelse«. Rygtet gik i november $1900 \mathrm{i}$ Egvad, at kommuneforstander Andreas Hansen i Øbening havde en søn, der gik på højskole i Danmark. Den meget tysksindede amtsforstander J. Hinrichsen lod gendarmen undersøge denne "utrolige sag«, som han kaldte den i indberetningen til von Uslar. Til forhørsprotokollen erklærede Hansen, at hans 16-årige søn Mathias ganske rigtigt $i$ en måned havde gået på efterskolen $i$ Holsted en mil nord for grænsen. Han gik der for at lære det danske sprog, og efter Hansens mening drejede det sig ikke om en af de politiserende såkaldte højskoler. Sagen havde intet (national-)politisk indhold, og det var hans hensigt næste år at sende sønnen på den tyske landbrugsskole i Aabenraa.

Amtsforstander Hinrichsen mente derimod, at der var tale om et så voldsomt tillidsbrud, at der måtte en disciplinærsag til. Han troede ikke på Hansens forklaringer, men mente, at denne var blevet forledt af sine dansksindede naboer. Uanset hvad skolen kaldte sig, så var også den et arnested for dansk politik.

von Uslar skrev derpå til kommuneforstander Hansen, om han frivilligt ville nedlægge sit hverv, da der ellers ville blive indledt disciplinærsag for at fjerne ham fra posten. Men det ville Hansen ikke, for han var sig ikke bevidst at have begået en tjenesteforseelse. Derpå indledte von Uslar den 20. december 1900 sagen på grundlag af $\S 2$ i disciplinærloven.

En undersøgelseskommission afhørte nu Hansen, og han gentog ved denne lejlighed, at Mathias gik på skolen for at lære sit modersmål, det danske sprog, ordentligt, og at han af en lærer fra skolen havde fået at vide, at der 
ikke i politisk henseende skete påvirkning af de unge mennesker. Det var som privatperson, at han havde sendt sønnen til Holsted, og han var i øvrigt tysksindet. Både før og efter sit valg til kommuneforstander havde han altid stemt tysk. Han var ikke medlem af nogen dansk forening, men tværtimod af Den Tyske Forenings lokalafdeling i Hellevad, omend han af uforklarlige årsager ikke havde betalt kontingent de senere år.

Et par tysksindede kommuneforstanderkolleger og et par gårdejere, der også blev afhørt, sagde derimod, at Hansens handling skyldtes påvirkning fra dansksindede naboer og det forhold, at de danske foreninger gav økonomisk støtte til et sådant skoleophold. Efter deres mening kunne han ikke forblive i embedet.

Anklageskriftet var udformet af von Uslars nære medarbejder, kancelliråd Scholz, og i dette blev udover sagen med efterskolen også inddraget et andet, to år gammelt, forhold, der var kommet frem under afhøringen, nemlig at Hansen havde deltaget $\mathrm{i}$ en forsamling hos gårdmand Jes Petersen, hvor den danske agitator, vandrelæreren Caspar Jensen havde deltaget. Konklusionen $i$ anklageskriftet var som venteligt, at Hansen beklædte et autoritativt tillidsembede, og at man måtte kunne forvente af ham, der havde aflagt troskabsed til kongen af Preussen, at han havde afholdt sig fra at anbringe sin søn på en tyskfjendtlig anstalt. Hansen havde gjort sig uværdig til sine foresattes tillid og måtte fjernes fra kommuneforstander-embedet.

Sagen skulle behandles i kredsudvalgets møde den 10.februar 1901, men måtte udsættes, fordi Hansen fik lungebetændelse. Da han var rask, blev mødet fastsat til den 16.april kl. 10 på Brundlund slot. Alle var mødt, bortset fra den anklagede.

Under von Uslars ledelse blev sagen alligevel gennemført. Scholz sagde bl.a., at en kommuneforstander havde et vigtigt æresembede, og de foresatte myndigheder måtte kunne have ubetinget tillid til ham. Hansen havde ikke levet op til tilliden, da han lod sig trække over på det danske parti og havde sendt sin søn på højskole i Danmark. Disse skoler var almindelig kendt som arnesteder for hadet mod al tyskhed, og eleverne plejede bagefter »at stille op i rækken af stedlige agitatorer«. Myndighederne kunne ikke have tillid til Hansen, og Scholz krævede ham afsat. Kredsudvalget fulgte helt dette synspunkt i sin dom.

Først skulle dommen forkyndes for Hansen i et nyt møde, og derpå blev han suspenderet fra embedet. Han benyttede sig af sin ret til at klage til Overforvaltningsretten i Berlin over sagens behandling, men indsendte sin klage for sent, hvilket von Uslar ikke undlod at påpege. Klagefristerne skulle overholdes, og Overforvaltningsretten afviste at behandle sagen. I stedet tilbagesendtes den til kredsudvalget i Aabenraa for at blive afgjort endeligt dér 
ved en forvaltningskendelse. Her afvistes den formelt, fordi klagefristen var overskredet. Som taber af sagen skulle Hansen betale omkostningerne. Det klagede han over, men igen for sent. Den 28. august 1902 måtte han bide i det sure æble og betale pengene. Da havde han allerede været afsat fra kommuneforstanderposten i over et å $\mathbf{r}^{39}$.

Sagen viser, at von Uslar og hans ligesindede i kredsudvalget var enige om at modvirke selv beskedne afvigelser fra den tyske linje. Mere interessant viser den også, at en uøvet person, der selv prøvede at føre sin sag, kom til kort over for von Uslar. Regeringspræsidenten påpegede dog over for ham, at han havde begået en mindre, formel fejl vedrørende fastsættelsen af omkostningerne. Det havde dog ingen betydning for sagens udfald. Vanskeligere fik von Uslar det, som vi skal se nedenfor, i sine konflikter med sine egentlige modstandere, de dansksindede og socialdemokraterne.

Konflikter med de dansksindede:

Folkehjems spiritusbevilling

I den nordlige del af Aabenraa lå forlystelsesstedet "Schweizerhalle« på en stor grund med restaurant, keglebane og dansepavillon. I 1901 købte "Foreningen til det danske Sprogs Bevarelse i Nordslesvig " (Sprogforeningen) ejendommen, fordi man manglede faste mødelokaler, plads til boglager, læseværelse m.m. Myndighederne lagde jo $i$ disse år hindringer $i$ vejen for de dansksindedes møder ${ }^{40}$.

Den danske bevægelse havde dermed fået et centralt tilholdssted i Aabenraa, hvad der bestemt ikke vakte begejstring hos von Uslar. Da han læste om salget $i$ avisen, blev han vred på politiet, som han mente burde have vidst, at noget sådant var i gære. Da køberen »Folkehjem« var et aktieselskab under dannelse, troede von Uslar dog, at han kunne nå at hindre salget, hvilket han indberettede til regeringspræsidenten. von Uslar mente, at en bemærkning i en forordning fra 1799 gav ham ret $i$, at jordsalget til en selvejende institution (»die tote Hand《) skulle godkendes af landråden. Så snart aktieselskabet var blevet dannet, ville han derfor gøre indsigelse imod salget, og han ville nægte tilladelse dertil. Regeringspræsidenten svarede ham dog kort, at den nævnte forordning var blevet ophævet ved $\S 89 \mathrm{i}$ udførelsesloven til den nye tyske borgerlige lovbog, der var trådt i kraft den 1.januar 1900. Det burde von Uslar nok snarere have været opmærksom på ${ }^{81}$.

Sprogforeningen omdøbte "Schweizerhalle« til »Folkehjem«, men der skulle stadig drives restauration på stedet. På dette punkt havde von Uslar gode muligheder for at hæmme sine modstanderes aktiviteter. Det var nemlig kredsudvalget med landråden som formand, der udstedte koncessioner til drift af gæstgiveri, beværtninger o.l., omend det skete efter indhentede udtalelser fra 


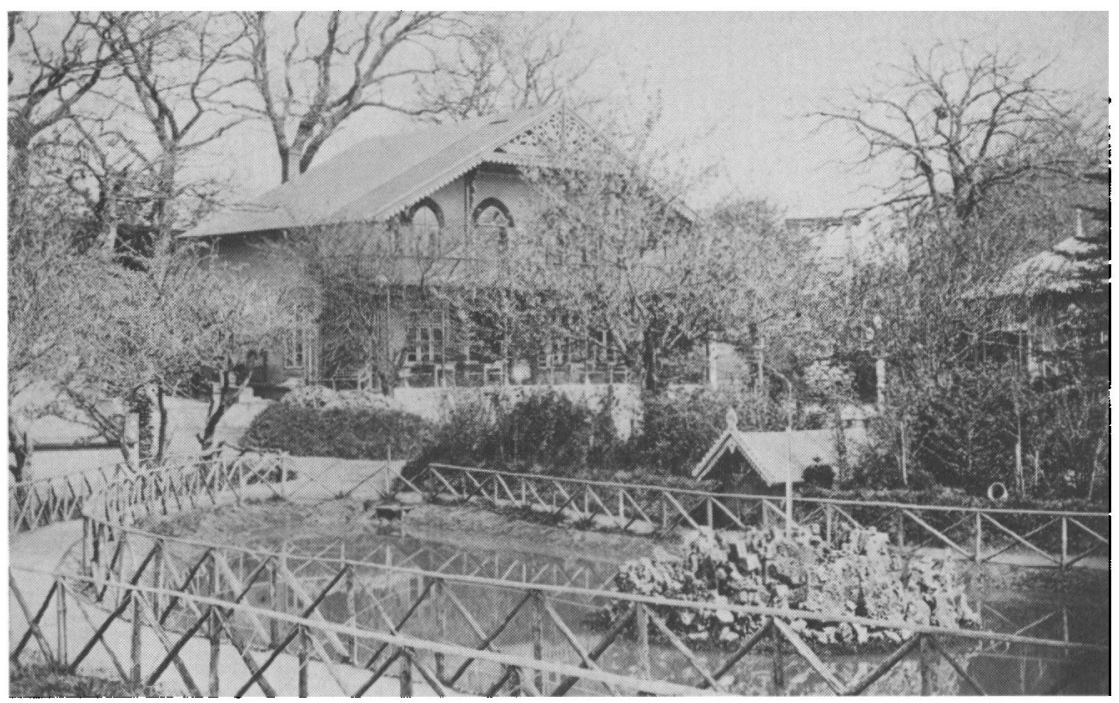

Restaurant "Schweitz" ved Aabenraa bys nordlige udkant var omgivet af et smukt haveanlag med damme, spadserestier og små Schweitzerhuse. Sprogforeningen kabte ejendommen i 1900 og omdannede den til det danske forsamlingssted Folkehjem. I 1910 blev den mod nord udvidet med en stor forsamlingssal. På det gamle Schweitz's plads ligger i dag Det sonderjyske Landsbibliotek. Foto J. H. Dorr $i$ Historiske Samlinger.

politimester og magistrat i Aabenraa. Der plejede dog at være overensstemmelse mellem de to sidstnæunte organer, sikkert fordi borgmester Rickmers i magistraten fremførte de samme synspunkter, som han havde som politimester. Hvis kredsudvalget afviste ansøgningen, kunne ansøgeren begære en mundtlig forhandling for udvalget $i$ en forvaltningsretstrætte. Kredsudvalgets afgørelse kunne indankes for distriktsudvalget i Slesvig, der i disse sager havde den endelige afgørelse. Næringslovens $\S 33$ bestemte, at afslaget skulle være begrundet $i$ en mistanke om, at ansøgeren ville misbruge koncessionen f.eks. til fylderi, at lokalerne ikke var tilstrækkelige, eller at der ikke fandtes tilstrækkeligt behov for et sådant udskænkningssted. Om der fandtes et behov afgjorde kredsudvalget imidlertid ganske efter eget skøn $\mathbf{n}^{42}$.

Det fremgår af forskellige koncessionssager i kredsudvalgets arkiv, at politimester Rickmers og magistraten i Aabenraa lige som kredsudvalget havde den grundopfattelse, at der var alt for let adgang til at drikke alkohol i byen. I 1900 var der til en hjemmehørende befolkning på omkring 6.000 personer 32 gæstgiverier, 28 beværtninger og 32 småhandlere med spiritussalg. Skulle forbruget begrænses, måtte det ske gennem koncessionerne, mente myndighederne. Man måtte ikke kun afvise nye ansøgninger om koncession, men også 


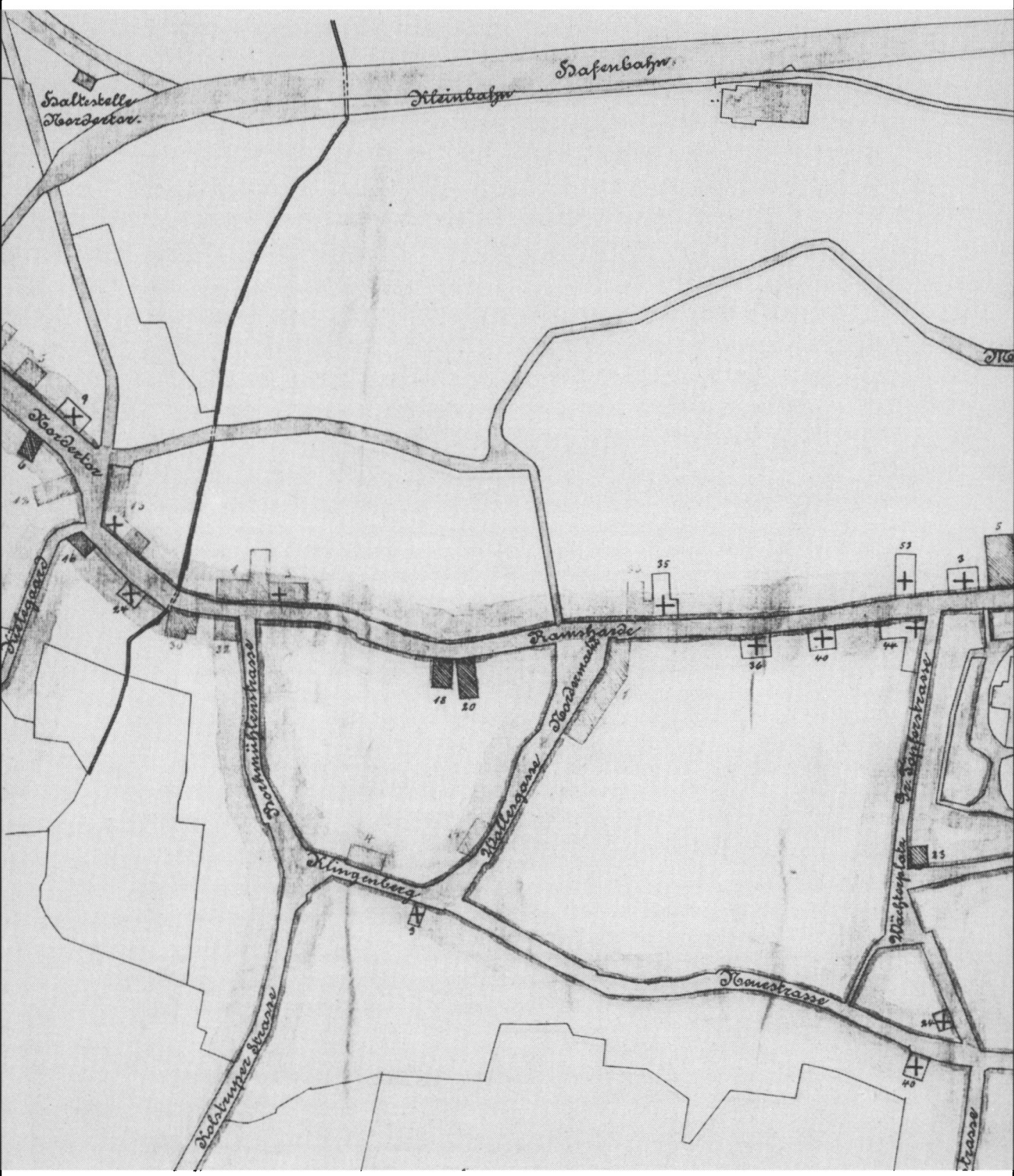

Kort fra 1904 over gastgiverier, hevartninger og småhandlende med spiritussalg $i$ Aabenraa. Det ses tydeligt, at man ikke skulle gå mange meter af hovedstrogene for at finde en bevartning eller et udsalgssted for spiritus. Med signaturen + er angivet udsalg med spiritussalg, de skraverede firkanter 


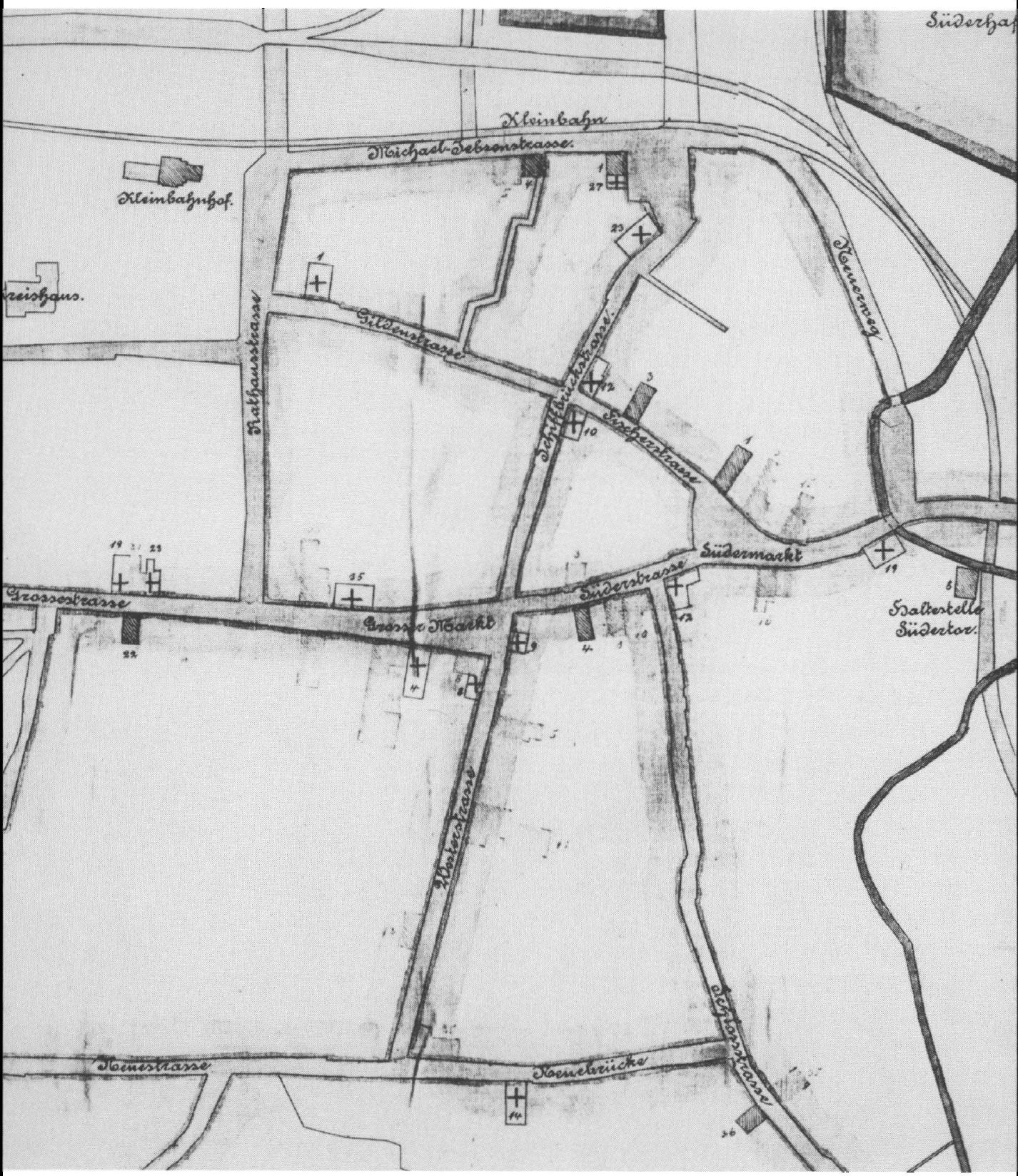

angiver gastgiverier, både med og uden spiritusbevilling. Luppis herberg ses som nr. 36 i Slotsgade nederst til hajre. Landsarkivet i Aabenraa. Kortsamlingen. 
tilfælde, hvor en eksisterende bevilling ønskedes fortsat efter arv eller andet ejerskifte, med mindre at gode stald- eller logiforhold talte for en fortsættelse af driften. Der gennemførtes en begrænsning af bevillingerne, som det fremgår af, at der i 1892 var gennemsnitlig 58 beboere for hvert udskænknings- og salgssted, mens der i 1914 var $95^{43}$.

Det ville således også under ikke-nationalpolitisk prægede forhold være vanskeligt at opnå en koncession til "Svejts« (Schweizerhalle), som stedet kaldtes på dansk, før det omdøbtes til "Folkehjem«. Sprogforeningen havde ansat agent Asmus Jensen som vicevært, og da han i foråret 1901 søgte om ret til at drive gestgiveri, fik han afslag. von Uslar havde som overordnet politimyndighed henvist politimester Rickmers til at afvise ansøgningen med den begrundelse, at der ikke fandtes noget behov. Både politi og magistrat afviste ansøgningen, da de blev spurgt, og den 16. april 1901 afslog kredsudvalget Jensens ansøgning ${ }^{44}$.

Det var dog kun begyndelsen på sagen. Den 13. august 1901 vendte Asmus Jensen tilbage med en ansøgning om koncession til udskænkning af alkoholfrie drikke. Han skrev, at mange damer $i$ årevis havde været vant til at komme der og nyde en forfriskning. Han ville derfor gerne kunne servere kaffe, te, chokolade, seltersvand, sodavand og limonade. Denne ansøgning afslog kredsudvalget også. Asmus Jensen bad derpå om en mundtlig forhandling i kredsudvalget som en forvaltningsretstrætte, og med sig havde han den skarpsindige journalist Nikolaj Andersen, der netop var blevet ansat som hjælpesekretær ved Sprogforeningen. I mødet bad Nikolaj Andersen om, at ansøgningens ordlyd »alkoholfrie drikke« måtte blive ændret til »ikke-spirituøse drikke«. Muligvis hentydede han dermed til, at $\$ 114$ i loven om forvaltningsmyndighedernes kompetencefordeling talte om tilladelse til udskænkning af brændevin, vin, øl eller andre spirituøse drikke. Med ordvalget antydedes måske, at kredsudvalgets retsgrundlag for at nægte koncessionen var spinkelt. Ved drøftelsen af en eventuel koncession til udskænkning af alkoholfrie drikke måtte spørgsmålet om behovet ikke inddrages ifølge et preussisk ministerialreskript fra 1861, og kredsudvalget ville åbenbart ikke anfægte Jensens personlige kvalifikationer eller lokalernes kvalitet. Nikolaj Andersen sagde også, at kredsudvalgene i Haderslev og Sønderborg havde godkendt tilsvarende ansøgninger. Og så fik Asmus Jensen sin koncession ${ }^{45}$.

Omtrent halvandet år efter overtog Nikolaj Andersen og hans hustru selv forpagtningen af Folkehjems restaurant. Han fik uden vanskelighed den samme tilladelse til udskænkning af ikke-spirituøse drikke ${ }^{46}$.

Politiet holdt øje med, om Nikolaj Andersen overholdt koncessionens bestemmelser. Da det viste sig, at han serverede såkaldt "Good-Templar« øl (afholdsøl) med under $2 \%$ alkohol, blev han ved amtsretten idømt en bøde 
på 10 mark eller en dags hæfte. Politimester Rickmers gjorde ham ved samme lejlighed opmærksom på, at spirituøse drikke var alle drikke med alkohol uanset procenten, og at han havde forbud mod at sælge sådanne.

Hvis publikum skulle komme på Folkehjem, var udskænkning af kaffe, te, limonade o.l. ikke tilstrækkeligt. Der måtte også kunne drikkes øl og vin, og derfor søgte Nikolaj Andersen den 16.oktober 1903, kort efter episoden med bøden, om koncession til at udskænke disse varer. Han nævnte selv hændelsen og gav den dårlige undskyldning, at han havde serveret dette afholdsøl, fordi han var gået ud fra den i hvert fald moralsk (!) berettigede slutning, at udtrykket »ikke-spirituøst« svarede til »ikke-berusende«. Nu havde han fået forbud mod selv det tyndeste $ø$ og måtte derfor søge en bevilling. Det afgørende spørgsmål var, om der fandtes et behov. Nikolaj Andersen hævdede i ansøgningen, at der ikke fandtes nogen fare for misbrug, da det kun var det socialt bedrestillede og dannede publikum, der kom på Folkehjem. Han havde bespist selskaber på mere end 200 personer, og den overvejende del af gæsterne ville ikke nøjes med at drikke seltersvand, kaffe eller mælk. Efter politiets forbud var det flere gange sket, at gæster fra de sydlige egne var gået bort fra deres bestilte mad, når de hørte, at der end ikke kunne serveres det lette brunøl til maden! Efter Nikolaj Andersens mening måtte et behov efter næringsloven være det, som et stort antal gæster ønskede.

Efter anmodning fra von Uslar benægtede politiet, at der skulle være noget behov for denne koncession. Det samme gjorde magistraten, og kredsudvalget afviste da ansøgningen den 19.december 1903. Nikolaj Andersen ønskede derpå en mundtlig forhandling for kredsudvalget som en forvaltningsretstrætte, men blev igen afvist. Efter kredsudvalgets vurdering skulle behovet ikke bedømmes ud fra en privatøkonomisk opfattelse, men ud fra ordens- og moralpolitiets standpunkt. I dommens præmisser henvistes til det store antal udskænkningssteder $\mathrm{i}$ byen, og at der i nærheden af Folkehjem fandtes hotel Danmark og desuden gæstgiverierne Sanssouci og Fernsicht, der ligeledes havde have.

Kredsudvalgets afgørelse var forvaltningsmæssigt ganske regulær, og det underliggende nationale aspekt havde indtil dette tidspunkt ikke været nævnt. Men det kom frem, da Nikolaj Andersen den 20. april 1904 indankede kredsudvalgets dom til distriktsudvalget i Slesvig. Han skrev til dette, at Folkehjem i de seneste år på grund af sin centrale beliggenhed i Aabenraa var blevet valgt som forsamlingssted for de større foreninger, der dækkede hele Nordslesvig. Derved skabtes et behov, idet intet andet gæstgiveri, hotel eller etablissement i Aabenraa og omegn kunne stille sine lokaler til rådighed for dem, hvad politi og magistrat måtte indrømme, skrev Andersen.

Antydningen af, at der lå national chikane bag kredsudvalgets afgørelser, 


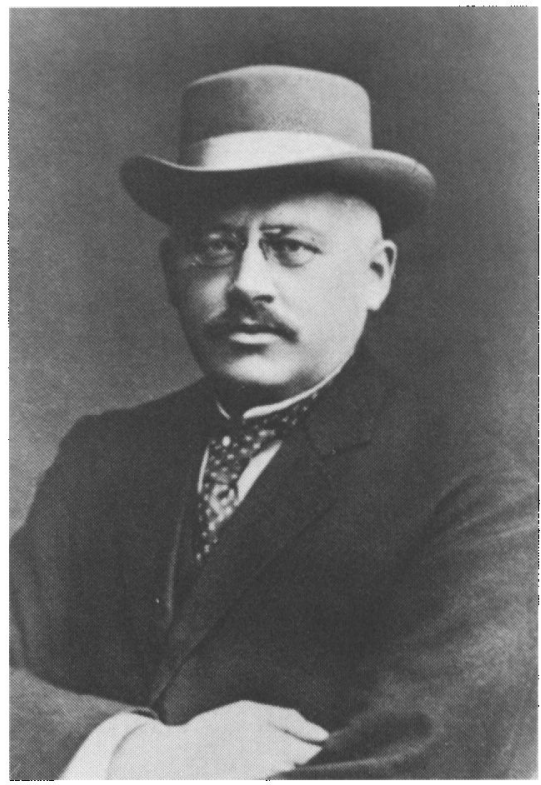

Gustav Rickmers, borgmester i Aabenraa 1898-1916. Her gengivet efter Abenrå bys historie bd. III, 1974.

bestyrkedes af bilagene til skrivelsen, for der var støtteerklæringer fra den dansksindede rigsdagsmand Jens Jessen, landdagsmændene H.P.Hanssen og Julius Nielsen, kredsdagsrepræsentanter osv. Derudover var der vedlagt en støtteudtalelse fra dansksindede borgere og en anden fra 15 erklæret tysksindede borgere i Aabenraa.

von Uslar bad politimester Rickmers om at forfatte en moderklæring til distriktsudvalget. Heri erkendte politimesteren, at Folkehjem var samlingsstedet for de agitatoriske danske foreninger. Han forklarede det således, at der i de almindelige gæstgiverier kun sjældent eller ikke skelnedes mellem enkeltpersoner af dansk eller tysk sindelag, men de agitatoriske foreninger behandledes anderledes. De fleste værter ville ikke have med dem at gøre, fordi de mente, at foreningernes skadelige formål fremmede utilfredsheden, og fordi de frygtede, at deres næring ville skades ved tabet af de daglige gæster. Således bortforklarede Rickmers myndighedernes kendte pres på gæstgiverierne, det såkaldte »Saalabtreiberei«. Efter hans mening var der ikke noget særligt behov for, at disse foreninger skulle beværtes i pauserne.

Rickmers forklarede, at de personer, der havde underskrevet bilagene næsten alle var medlemmer af disse foreninger. Han prøvede også at bagatellisere den tyske støtteerklæring ved at hævde, at sådanne underskrifter blev givet af venlighed eller forretningsinteresse, og at folk ikke bedømte behovet, men blot 
mente, at et gæstgiveri til ikke ville kunne skade. Rickmers tillagde derfor ikke støtteerklæringerne nogen betydning og benægtede atter behovet for en koncession.

Ved den mundtlige forhandling i distriktsudvalget den 22.juni 1904 var Nikolaj Andersen repræsenteret ved advokat Crespel fra Flensborg, men trods denne sagkyndige bistand gik dommen Andersen imod. Man skulle nu mene, at slaget var tabt efter denne klageafgørelse ved den højeste instans. På grund af uforsigtighed eller manglende konsekvens i kredsudvalgets afgørelser i den følgende tid blev det dog ikke tilfældet ${ }^{47}$

Et halvt år senere indsendte Nikolaj Andersen en ny ansøgning om koncession til kredsudvalget, men denne gang kun til en begrænset ret til at udskænke $ø$ med højst $2 \%$, som "Good Templar « øl, brunøl, dobbeltøl o.l. Han fremførte i sin ansøgning bl.a., at borgmester Rickmers havde sagt til ham, at den tidligere afvisning ikke var sket ud fra politiske motiver, hvad der også ville have været ulovligt. Det havde kun været for at begrænse udskænkningen af alkohol, og Nikolaj Andersen hævdede nu, at det var af samme grund, at han kun søgte om en begrænset tilladelse til svagt øl. Han kom også med en bemærkning om, at ejerne af Fernsicht og Bellevue i mellemtiden havde fået koncession til spirituøse drikke. Behovet herfor måtte altså være steget betydeligt, konkluderede han ironisk. Derfor kunne man vel ikke betvivle, at der fandtes et behov for udskænkning af de langt mindre mængder alkohol, der var i "Good Templar" øl.

Landråd von Uslar var dermed tydeligt sat i klemme. I første omgang svarede han Nikolaj Andersen, at den nye ansøgning ville indebære gæstgiveri med alkoholholdige drikke. Da distriktsudvalget havde truffet den endelige afgørelse i den sag, så betvivlede von Uslar, at ønsket kunne efterkommes. Han henstillede til Nikolaj Andersen, at han trak ansøgningen tilbage.

Men Andersen var ikke villig til at give op, og der var heller ikke grund til at gøre det, for Overforvaltningsretten havde i en kendelse 1879 fastslået, at en fornyet ansøgning om koncession ikke kunne afvises, blot fordi en tilsvarende ansøgning fra samme ansøger tidligere var blevet afslået. Men i dette tilfælde gik Nikolaj Andersen $\mathrm{i}$ et svar til landråden ind på forskellen i de to ansøgninger. Han kunne ikke indse, at det tidligere afslag vedrørende alkoholholdige drikke $\mathrm{i}$ almindelighed skulle være involveret, når det kun drejede sig om en begrænset del af det tidligere ønskede. Eller betød det måske, at han faktisk ville få tilladelse til fuldt gæstgiveri, hvis han fik tilladelse til udskænkning af øl med højst 2\% alkohol? Det ville den logiske Nikolaj Andersen meget betvivle. Og når der blev anerkendt et behov ved at give bevilling til andre steder, så kunne han ikke se, hvorfor behovet for let øl til indtagelse sammen med mad på forhånd skulle afvises. 


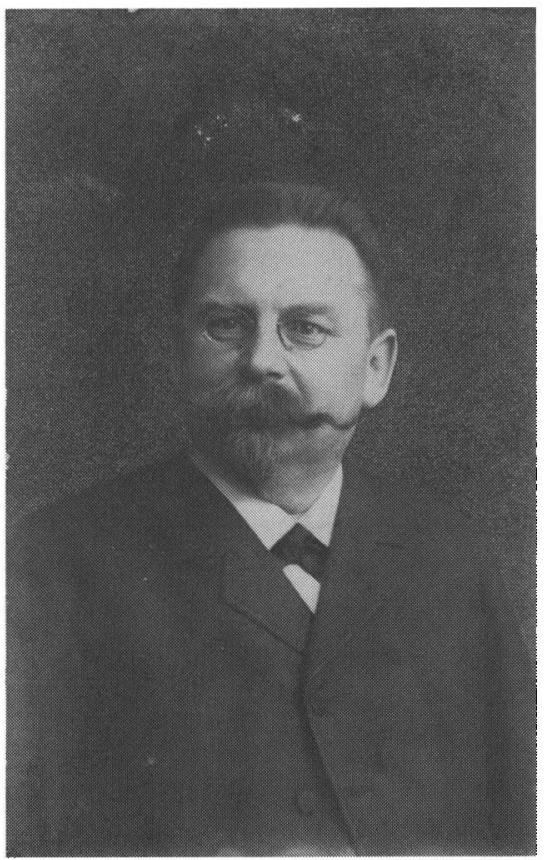

Sprogmanden, matematikeren og forfatteren $\mathrm{Ni}$ kolaj Andersen var Sprogforeningens sekretar og bibliotekar fra 1900 til sin dod 1919. Foto Clausen i Historiske Samlinger.

Magistraten i Aabenraa og politimester Rickmers afviste dog den nye ansøgning, og det samme gjorde kredsudvalget. Efter denne afgørelse bad Nikolaj Andersen sagen behandlet som forvaltningsretstrætte, hvilket skete i kredsudvalgets møde den 2.november 1905. Han gentog ved denne lejlighed, at han kun havde søgt om tilladelse til alkoholfattigt øl, og at det ville være helt $\mathbf{i}$ lovens ånd med en sådan koncession, for ellers ville gæsterne blot indtage stærkere drikke andetsteds. Med henvisning til Fernsicht og Bellevue anmodede han om, at han tilnærmelsesvis blev målt med samme målestok som besidderne af disse to etablissementer.

Kredsudvalgets overvejelser kendes ikke, men åbenbart fik Andersens krav om ligebehandling og muligheden af, at han ville indanke sagen for distriktsudvalget, kredsudvalget til at ændre sin beslutning. Det ville utvivlsomt have være vanskeligt for von Uslar og Rickmers denne gang over for distriktsudvalget at argumentere for, at der var sket en objektiv behandling af denne ansøgning. Dertil kom det heller ikke, for kredsudvalget besluttede, at Nikolaj Andersen skulle have koncession til udskænkning af øl med højst $2 \%$ alkohol ${ }^{48}$.

I nogen tid klarede Nikolaj Andersen sig med denne ret til udskænkning af let $ø$ l. Men i 1909 søgte han om ret til at måtte udskænke almindeligt øl, vin 
og likør. Landråd von Uslar henviste, som han plejede, politiet til at benægte, at der eksisterede noget behov, og bad på kredsudvalgets vegne om magistratens og politiets udtalelser. Denne gang fik han det overraskende svar, at magistraten og politiet gik ind for en koncession til øl og vin! Det samme gjorde kredsudvalget i sit møde den 7.oktober 1909.

Der er ikke nogen argumentation i svarene fra magistraten og politimesteren eller i kredsudvalgets akter. Derfor kan det kun blive et gat, hvorfor Nikolaj Andersen uden sværdslag fik størstedelen af sin ansøgning bevilget imod von Uslars ønske. Måske skal det ses i sammenhæng med, at von Uslar under sit ophold i Sydvestafrika 1906-08 havde mistet sin hidtidige politiske indflydelse i kredsen. Hans stedfortræder, Dryander, havde anlagt en anden, mere fleksibel politisk linje49. Det var den sidste kamp om en koncession til Folkehjem. Selv om det tog lang tid, fik Nikolaj Andersen dog lidt efter lidt sin koncession til de dansksindedes samlingssted, og imod von Uslars vilje. Det var egentlig overraskende godt klaret, når man erindrer, at landråd von Uslar og kredsudvalget med hensyn til behovet havde et ganske selvstændigt skøn.

\section{St. Jorgens frimenighedskirke}

I midten af 1890'erne konstaterede myndighederne, at den grundtvigske bevægelse havde spredt sig til Aabenraa. Der blev i 1895 dannet et "Udvalg for kristelig Virksomhed i Nordslesvig «, der fra tid til anden også holdt gudstjenester i Aabenraa. De fandt sted på hotel Phønix, så på Colosseum og derefter på hotel Danmark i Nørreport, indtil også hotelværten dér i juni 1900 efter pres fra myndighederne nægtede at lade danske møder afholde i sine lokaler. Derpå foregik de på Folkehjem ${ }^{50}$.

Landråd von Uslar mente om grundtvigianerne, at det var fanatiske danskere, som der både i statskirkelig og nationalpolitisk interesse måtte sættes en stopper for. Deres aktiviteter var afgjort mest politisk bestemt til fordel for den danske agitation, eller kort sagt, mere politik end religion ${ }^{51}$. Da Udvalget for kristelig Virksomhed var dannet, forlangte han, at der skete en bedre politimæssig overvågning. Der blev ansat en politisergent i Aabenraa, C.C.Matzen, der kunne sønderjysk, hvad politimester Vreden ikke kunne. von Uslar syntes, at Vreden var for moderat, og han var heller ikke tilfreds med efterfølgeren, Rickmers. I anden sammenhæng klagede von Uslar i 1900 til regeringspræsidenten over, at Rickmers manglede initiativ og desværre oftest måtte holdes til politimæssig indskriden af ham selv². Selv om von Uslar holdt dem til ilden, så kom der dog ikke meget ud af overvågningen. Et eksempel på landrådens nidkærhed var, at han forlangte en nøje undersøgelse af, om der ikke havde opholdt sig for mange personer i Folkehjems lokaler ved en gudstjeneste, hvis man gik ud fra forskrifterne i byggelovgivningen ${ }^{53}$. 
En langvarig strid om bygning af frimenighedskirker i Bovlund og Haderslev var den 11.maj 1900 endt med, at Overforvaltningsretten havde ophævet de administrative myndigheders forbud. $\mathrm{Da}$ der var en nær forbindelse til frimenigheden i Aabenraa, syntes det naturligt, at tanken om at bygge en kirke også skulle dukke op dér. von Uslar bad omkring denne tid politiet om øjeblikkelig indberetning, hvis det skulle blive kendt at man byggede en kirke eller indrettede særlige rum varigt til dette formål. Da han hørte Overforvaltningsrettens dom, beklagede han afgørelsen ${ }^{54}$.

I foråret 1902 havde menigheden besluttet at bygge en kirke på et område ved siden af Folkehjem, og Sprogforeningen ville gratis afgive et grundstykke. Ud fra enkelte avisnotitser og oplysninger fra politiet kunne von Uslar følge forberedelserne til byggeriet, men måtte ellers blot vente. Den 13. november 1902 affattede hovedmændene i frimenighedens byggeudvalg, kaptajn C.C. Fischer, tobaksfabrikant M.Andresen og landdagsmand H.P.Hanssen ansøgningen om tilladelse til at bygge en kirke. Den kom på von Uslars bord i stedet for på politimesterens, men skulle derfra til prøvelse hos kredsbyggeinspektør Jablonowski i Haderslev. Det var nok von Uslar selv, der i irritation påtegnede ansøgningen: »Weshalb?« - hvorfor? Tegningen, beskrivelse og situationsplan for kirken blev sendt til landråden 5.december 1902, og her fik de lov til at ligge de næste to måneder. Men von Uslar skrev straks til sine overordnede, regeringspræsidenten og overpræsidenten, for at forhindre projektet $^{55}$.

Da Overforvaltningsretten efter en grundig behandling af spørgsmålet om bygning af frimenighedskirken havde fastslået, at der intet lovmæssigt grundlag fandtes for at forbyde det, ville von Uslar fortsætte kampen med andre lovbestemmelser, nemlig vedrørende udvisninger af optanter og med bygningslovgivningen. von Uslar havde tidligere ved en gennemgang af embedets optionssager fundet ud af, at Fischers papirer ikke var ganske i orden. Han ønskede at få Fischer udvist, men overpræsident Wilmowski, der i 1901 havde afløst von Köller, ønskede tilbageholdenhed og ville ikke presse Fischer ind $\mathrm{i}$ en martyrrolle. $\mathrm{Nu}$ argumenterede von Uslar over for sine overordnede for, at man umuligt kunne ignorere Fischers underskrift på ansøgningen, hvor denne »danske undersåt« (dvs. optant) havde underskrevet ved siden af de to danske hovedagitatorer M.Andresen og H.P.Hanssen, og give ham tilladelse til en bygning, der skulle bruges til agitation imod tyskheden. Byggeselskabet var udgået fra de danske foreninger, og Sprogforeningen havde vel leveret en stor del af pengene til bygningen. Det ville blive et forsamlingshus for grundtvigianerne, som helt sikkert dannede et dansk oppositionsparti, skrev von Uslar. Til overpræsidenten tilføjede han, at Fischer var lederen og den driftigste agitator for iværksættelsen af byggeriet $^{56}$. 


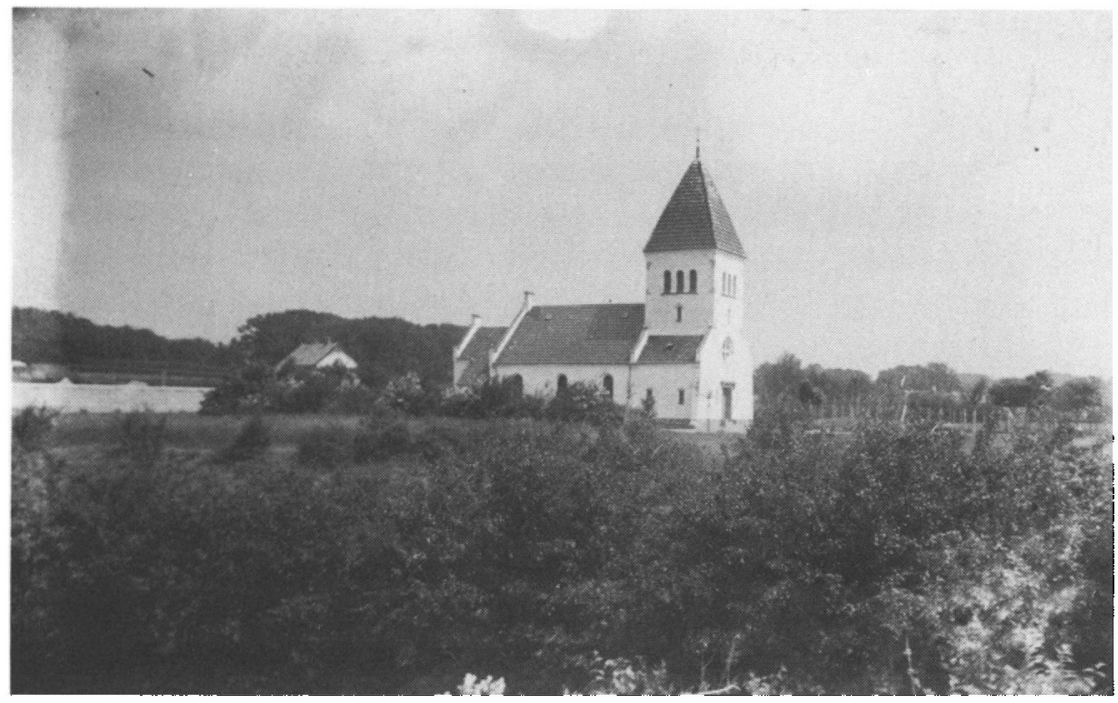

Skt. Jorgens kirke nord for Aabenraa blev opfort 1903-04 med N. Jacobsen som arkitekt. På dette foto fra 1910 knejser kirken pd Kirkebakken uden omgivende bebyggelse. Historiske Samlinger.

Regeringspræsidentens svar den 20.januar 1903 var afdæmpet, hvilket skal ses $\mathrm{i}$ sammenhæng med, at regeringerne $\mathrm{i}$ Berlin og København $\mathrm{i}$ disse år prøvede at få et venskabeligere forhold mellem de to stater. Med henvisning til Overforvaltningsrettens kendelse afviste regeringspræsidenten over for von Uslar, at man kunne nægte bygningen af kirker for ikke-landskirkelige foreninger. Der kunne heller ikke udledes nogen grund dertil af den omstændighed, at Fischer havde underskrevet ansøgningen, og at forvaltningen anså ham for udlænding. Tilladelsen til at bygge ville kun kunne afslås, hvis den blev retfærdiggjort ved andre grunde i den offentlige byggeret ${ }^{57}$.

von Uslar gav dog ikke op, selv om han ikke havde fået medhold hos sine overordnede. Da han endelig i februar 1903 sendte tegningerne til prøvelse hos kredsbyggeinspektør Jablonowski, skete det åbenbart med en anmodning om at standse sagen ud fra bestemmelserne om forsamlingshuse. Jablonowski mente ikke, at det var et forsamlingshus, men fandt i øvrigt, at der også var taget hensyn til bestemmelserne for et sådant, for så vidt de kunne komme på tale her. Han påpegede, at prøvelsen af projektet hørte til det lokale politis opgaver (dvs. ikke til von Uslars). Hvis politiet onskede, at han vurderede projektet, kunne det henvende sig direkte til ham. Det var en tilrettevisning af landråden $\mathrm{i}$ forvaltningsmæssig henseende.

Kredsbyggeinspektøren sendte sin vurdering til regeringspræsidenten, der over for von Uslar gentog, at man ikke kunne nægte byggetilladelsen, uanset 
om byggeriet blev anset for en kirke eller et forsamlingshus. Dermed havde von Uslar tabt kampen imod byggeriet. Kort efter bad politiet Jablonowski om at gennemgå byggeplanerne, hvilket kun førte til krav om nogle små ændringer ${ }^{58}$.

Ganske vist kunne landråden ikke længere standse byggeriet, der blev færdigt i marts 1904, men han formåede stadig at forsinke det noget $\mathrm{i}$ efteråret 1903 ved at true arbejderne med udvisning. I et fortroligt brev til politimester Rickmers personligt bad han denne om mundtligt at true seks tømrere og murere, der var danske statsborgere, med udvisning, hvis de ikke straks søgte arbejde andetsteds. Hemmelighedskræmmeriet skyldtes, at von Uslar ikke havde ret til egenhændigt at true med udvisning. Arbejderne reagerede på truslen og forlod byggeriet. Men fremgangsmåden virkede ikke over for et par arbejdere, som bygmesteren så satte til arbejdet. Nu blev von Uslar nødt til at sikre sig regeringspræsidentens støtte til sagen. Den fik han ganske vist, men samtidig tildelte regeringspræsidenten ham en »næse« for egenmægtigt at have svunget udvisningsvåbnet over de første arbejdere. Regeringspræsidenten forbeholdt sig retten til udvisning, efter at landråden havde undersøgt retsgrundlaget. De arbejdere, som det $\mathrm{i}$ anden omgang drejede sig om, foretrak at arbejde andetsteds, da de (med regeringspræsidentens godkendelse) blev truet med udvisning. Arbejderne gav over for politiet udtryk for deres utilfredshed, da de gik, og de sagde, at de ville klage til landråden! De vidste ikke, at det var ham, der stod bagss.

Kampen mod frimenighedskirken i Aabenraa viser klart, hvordan von Uslar også efter overpræsident von Köllers afgang ivrigt og på eget initiativ bekæmpede det danske parti på et område, hvor der næppe kunne være tale om noget statsfjendtligt forhold. Kunne den lige juridiske vej ikke benyttes, så anvendte han anden lovgivning og udvisning for at nå sit mål.

\section{Konflikter med socialdemokraterne:}

\section{"Gewerkschaftskartell" og foreningslovgivningen}

Arbejderbevægelsen i Aabenraa opstod i begyndelsen af 1870'erne og tidligere end andetsteds i Nordslesvig. En socialdemokratisk forening blev dannet $\mathrm{i}$ 1872 , men standsedes efter et par års forløb af myndighederne. I 1878 gennemførtes en socialistlov, der frem til 1890 fratog socialdemokraterne i hele Tyskland de politiske rettigheder bortset fra retten til at stemme eller at blive valgt.

$\mathrm{Da}$ arbejderbevægelsen i Aabenraa igen lovligt kunne organisere sig, var det ikke en politisk forening, men fagforeninger, der etableredes. Igennem 1890 'erne dannedes flere fagforeninger eller afdelinger af de landsdækkende forbund, og endelig i juli 1900 oprettedes et »Gewerkschaftskartell«, svarende til en Arbejdernes Fællesorganisation, der havde til opgave at fremme fagfor- 
eningernes fælles interesser. Der var fem medlemsorganisationer fra starten, nemlig bogtrykkernes, murernes, tømrernes, snedkernes og arbejdsmændenes foreninger. Fællesorganisationens første formand faktor Elsner meddelte den 13.juli 1900 politiet, at to delegerede fra hver af foreningerne ville holde møde den første torsdag i hver måned kl. 20.30 om aftenen i Luppis svendeherberge i Slotsgade. Det var næsten nabo til landråd von Uslar på Brundlund $\operatorname{slot}^{60}$.

Landråden brød sig ikke om den socialdemokratiske arbejderbevægelses aktiviteter, og denne modvilje delte han sikkert med de fleste preussiske embedsmænd. von Uslar havde gode muligheder for at være orienteret om, hvad der foregik i Fællesorganisationen ligesom i alle andre foreninger og forsamlinger i Aabenraa kreds. I henhold til den preussiske forsamlings- og foreningslov af 11.marts 1850 havde politiet ret til at overvære alle forsamlinger, i hvilke der blev drøftet offentlige anliggender, og resultatet af overvågningen tilflød jæunligt landråden ${ }^{61}$.

Igennem det første halve år fulgte politiet, hvordan Fællesorganisationen var aktiv bl.a. med at søge oprettet et arbejdsanvisningssted for de rejsende og med at arrangere, at de fagligt organiserede arbejdere kun købte hos bagere og købmænd, der ville levere varerne til en lavere pris. Det var dog ikke disse emner, men en forholdsvis lille sag, en ansegning om at måtte afholde en fagforeningsfest, som udløste sammenstødet med landråd von Uslar og politimester Rickmers.

Allerede før ansøgningen blev indsendt, havde landråden haft et samråd med politimesteren og aftalt med ham, at tilladelsen ikke skulle gives. En fest ("Kränzschen«) ville medføre, at kvinder deltog deri, og det ville være i strid med forsamlings- og foreningslovens bestemmelser. Loven gik i korthed ud på, at alle forsamlinger, $\mathrm{i}$ hvilke der blev drøftet offentlige anliggender, skulle anmeldes til politiet et døgn før, de blev afholdt. Både begrebet "forsamling" og woffentlige anliggender « blev opfattet meget bredt. Politiet havde ret til at overvære en sådan forsamling eller møde og kunne f.eks. opløse den, hvis der behandledes forslag, der indeholdt en opfordring til strafbare handlinger. Reglerne for forsamlinger, der drøftede offentlige anliggender, gjaldt også for foreninger, men de var tillige underlagt nogle særlige bestemmelser. Der skelnedes mellem foreninger, som tilsigtede at indvirke på offentlige anliggender, og foreninger, som havde til formål at drøfte politiske emner i forsamlinger. Bestyrelsen for foreninger af den førstnæunte art var forpligtet til senest tre dage efter foreningens stiftelse at indlevere dens love og medlemslister til politiet. Ændringer i lovene eller i medlemsskaren, også ved død (!) skulle under strafansvar meldes til politiet senest tre dage efter de var sket. Endnu strammere bestemmelser gjaldt for foreninger af den sidstnæunte art, de politiske foreninger, idet der til det allerede næunte kom, at de hverken måtte 
optage kvinder, elever eller lærlinge som medlemmer, eller lade dem deltage i foreningens møder ${ }^{62}$.

Da Fællesorganisationens formand den 8.november 1900 ansøgte politiet om tilladelse til at afholde festen, fik han afslag. Ved en henvendelse til von Uslar lød svaret, at landråden ikke var i stand til at ændre politiets afgørelse. Til sidst henvendte Fællesorganisationen sig da til regeringspræsidenten, der gav politiet ret. Selv om Fællesorganisationen ikke ville betegne sig selv som en politisk forening, så fremgik det af dens egne og medlemsorganisationernes protokoller, at der faktisk blev drøftet politiske forhold. Regeringspræsidenten mente derfor ikke, at det var tilladeligt, at foreningen arrangerede et møde med kvindelig deltagelse. Så det blev ikke til noget med den fest.

Ved sin stiftelse havde Fællesorganisationen afleveret sine statutter til politiet, men ikke nogen medlemsfortegnelse. Sagen med festen havde vist, at også de øverste myndigheder opfattede Fællesorganisationen og fagforeningerne som politiske foreninger, og derfor pressede politimesteren på for at få opfyldt foreningslovens bestemmelse om aflevering af medlemslister og love. På Fællesorganisationens møde den 25 . november 1900 var man enig om at afvise dette krav, da man ikke var en politisk forening, lige som fagforeningerne ikke var det. Fik myndighederne ret, ville deres indflydelse på organisationerne vokse. I et senere møde sagde murer Ewald, at en murer Riesgaard, der var dansk undersåt, havde fået forbud mod at være medlem af murernes bestyrelse og mod at deltage i politiske forsamlinger. Det var således et væsentligt spørgsmål, hvordan Fællesorganisationen skulle defineres i forhold til foreningsloven ${ }^{63}$.

Da fagforeningerne, med undtagelse af tømrerne, og Fællesorganisationen nægtede at efterkomme politiets krav, gav politiet formændene bøder. Elsner bad imidlertid om en retlig afgørelse af sin bøde på 3 mark eller 1 dags hæfte, hvilket ville sige, at en domsmandsret (»Schöffengericht«) ved Amtsretten i Aabenraa skulle behandle den som en straffesag af mindre betydning. Det skete den 16.januar 1901, og dommen lød til politimester Rickmers' forbløffelse på frifindelse. Han havde som offentlig anklager taget for let på bevisførelsen for, at det var en forening, der indvirkede på offentlige anliggender, og derfor tabt sagen.

Endnu samme dag skrev Rickmers til von Uslar, at han ville appellere sagen til straffekammeret ved Landsretten i Flensborg. Han fremførte over for landråden, at politiet opfattede Fællesorganisationen og fagforeningerne som politiske foreninger, men $\mathrm{i}$ den foreliggende sag drejede det sig om pligten til at aflevere foreningslove og medlemslister. Dertil var ikke kun de politiske, men alle foreninger forpligtet, som indvirkede på offentlige anliggender. Politimesteren henviste til referaterne om Fællesorganisationens planer, der dokumenterede indvirken på offentlige forhold. von Uslar mente dog ikke, at man 
skulle være så forsigtig, fremgår det af hans kommentar. I slutningen af appellen ville han henvise til en Overforvaltningsretsdom af 3.marts 1899 om en fest, der skulle have været arrangeret af en tekstilarbejderfagforening. Ved denne dom havde retten også tillagt foreningens karakter betydning ved bedømmelsen ${ }^{64}$. von Uslar syntes ikke, at det var passende at overlade Landsretten afgørelsen af, om Fællesorganisationen m.m. var politiske foreninger. Landråden ville altså hellere gå lige på og hårdt.

I politiets indlæg over for Landsretten blev der ført omhyggeligt bevis for, at Fællesorganisationens aktiviteter måtte opfattes som indvirken på offentlige anliggender. Det bestred Elsner i sit indlæg, og derudover skrev han, at der ikke var tale om en forening i lovens forstand. Medlemmerne af Fællesorganisationen var ikke fysiske personer, men juridiske personer, de enkelte fagforeninger. Denne påstand skulle senere føre Fællesorganisationens sag til sejr.

Landsretten gav dog politiet ret. Elsners indvending blev afvist med følgende bemærkning. Fællesorganisationen var som sammenslutning af fagforeninger også en sammenslutning af disses bestyrelsesmedlemmer hhvs. medlemmer til et fælles formål. Politiets eksempler viste, at formålet var at indvirke på offentlige anliggender. Derfor var Fællesorganisationen forpligtet til at aflevere love og medlemslister. På grund af sin hidtidige uplettede vandel fik Elsner dog kun en bøde på 15 mark eller 3 dages hæfte, som var lovens mindstestraf.

På et møde i Fællesorganisationen den 3.marts 1901 var der bred enighed om at anke dommen til Kammerretten i Berlin, der i visse tilfælde fungerede som overlandsret for de tidligere hertugdømmer. Det kunne blive dyrt, så man forpligtede sig til i givet fald at betale 150 mark til dækning af omkostningerne. I referatet fra mødet nævnes, at man havde løfte om hjælp fra Fællesorganisationen $\mathrm{i}$ Berlin $^{65}$. Bag den sidste bemærkning lå sikkert, at man vidste, at Fællesorganisationen $i$ hovedstaden kort forinden havde ført en identisk sag til tops ved Overforvaltningsretten og vundet den ${ }^{66}$.

Da Kammerretten afsagde dom i ankesagen den 20.maj 1901, blev Elsner frikendt. Kammerretten fremhævede, at den netop mht. en fællesorganisation i en tidligere dom af 16.november 1899 havde fastslået, at den var en sammenslutning af juridiske personer, og ikke en forening. Medlemmerne af en forening i foreningslovens betydning var fysiske personer. Denne opfattelse havde Overforvaltningsretten tilsluttet sig ved to domme, senest den 12. februar 1901 i de berlinske arbejderes sag. Dette var det afgørende, og det var derefter uvæsentligt, at Fællesorganisationen kunne konstateres at indvirke på offentlige anliggender.

Den nye formand for Fællesorganisationen i Aabenraa, Hermel, omtalte sejren på et repræsentantmøde den 7.juni 1901, og hvordan man nu ikke længere behøvede at være ængstelig for myndighederne. Selv om man i konse- 
kvens af dommen ikke længere behøvede at anmelde Fællesorganisationens møder til politiet, så var det ham ligegyldigt. Egentlig så han helst, at møderne også i fremtiden blev overvåget, så myndighederne ikke troede, at der blev brygget noget sammen i deres forsamlinger! Politirapporten med arbejdernes spydige bemærkninger på dette møde nåede også frem til von Uslar ${ }^{67}$.

Det forekommer bemærkelsesværdigt, at Rickmers og hans overordnede $\mathrm{i}$ politisager, von Uslar, lod det komme til en sag ved Kammerretten. Kammerrettens tidligere dom i 1899 vedrørende et identisk forhold var netop blevet udgivet på tryk, og det var vel ikke venteligt, at retten ville ændre mening uden videre. Måske kan man konkludere, at von Uslar med en større grad af juridisk kendskab, særlig til Kammerrettens årbog, nok kunne have undgået nederlaget ${ }^{68}$.

\section{Bevillingen til Luppis herberg}

Luppis svendeherberg i Slotsgade var et vigtigt samlingssted for fagbevægelsen og socialdemokraterne omkring århundredskiftet. Det havde vel eksisteret $\mathrm{i}$ 80-90 år og var fra omkring 1870 blevet drevet af murermester og gæstgiver Johann W.E.Luppi. Her overnattede de vandrende svende, drak og diskuterede formentlig også politik. De høje embedsmænd på det nærliggende Brundlund slot var ikke tilfreds med forholdene, og under von Uslar lykkedes det at få herberget lukket.

Allerede landråd von Bonin havde opfordret politimester Vreden til at udøve den skarpest mulige kontrol med herberget og at hindre, at de arbejdssky og brændevinsforfaldne personer tog længere ophold på stedet. Der havde gennem længere tid været problemer med den politimæssige kontrol af de vandrende svende, der overnattede hos Luppi og i »Herberge zur Heimat«. Efter von Bonins mening skulle de to herberger ikke behandles ens af politiet, tværtimod skulle det kristelige Zur Heimat behandles mildt, da dets beståen var et af de bedst forebyggende midler imod wsocialdemokratiets fordærvelige vranglære $\ll^{69}$.

Da Johann Luppi efter en alvorlig sygdom døde den 23.december 1897, begyndte myndighederne nok at overveje at afvikle herberget. I første omgang fik Luppis enke dog tilladelse til sammen med sønnen Robert at drive det videre, og efter politiets opfattelse gjorde de det mere ordentligt end før. Den unge Luppi søgte endda i 1901 en tilladelse til, at de rejsende svende kunne overnatte langere hos ham, men det afviste politiet $\operatorname{dog}^{70}$.

Den 30.januar 1902 døde også enken Helene Luppi, og så begyndte der at ske noget. En fagfælle til snedker Robert Luppi, Hans Christian Erichsen fra Flensborg, søgte en uge efter om den fulde koncession til svendeherberget og lovede at forbedre forholdene ved at placere gastestuen bagtil, hvis han fik 


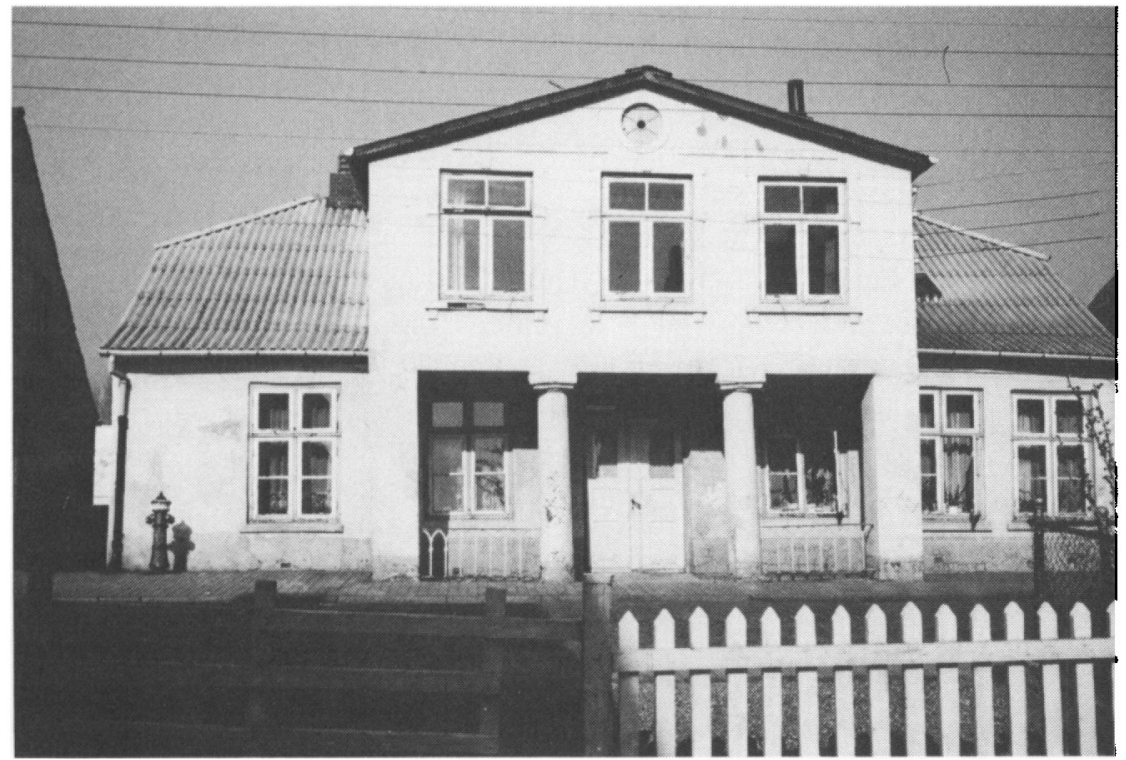

Luppis herberg. Slotsgade 40, fotograferet kort for nedrivningen i 1972. Historiske Samlinger.

bevillingen. Magistraten afviste ansøgningen, da der ikke var noget behov ud over Zur Heimat, og kredsudvalget afviste ligeledes ansøgningen p.g.a. manglende behov i h.t. Næringsloven.

Erichsen begærede nu en mundtlig forhandling for kredsudvalget $i$ en forvaltningsretstrætte, og som bilag til sin anmodning vedlagde han en petition, der havde cirkuleret i begyndelsen af februar, og som var underskrevet af et omfattende antal arbejdere og håndværkere, ikke mindst snedkere. Heri hed det, at de havde erfaret, at myndighederne uvist af hvilken grund ikke ville tillade en bevilling til »Centralherberget« (dvs. Luppis herberg). Ganske vist behøvede det ikke koncession, hvis der ikke var udskænkning, som angivet $\mathrm{i}$ Næringsloven, men det kunne ikke betale sig at drive så billigt et sted, hvis ejeren ikke havde ret til salg af alkoholiske drikke. Det hævdedes i petitionen, at strømmen af svende fra nord mod syd og omvendt især om vinteren var så betydelig, at Zur Heimat ikke engang kunne huse halvdelen. Uden Luppis herberg ville resten komme til at overnatte under åben himmel eller i detentionen. Man ville kunne undgå en stigning i hændelige brande og tyverier, hvis de farende svende ikke skulle dele skæbne med de omstrejfende tiggere, men fortsat kunne have deres herberg.

Den 22.april 1902 mødte Erichsen sammen med sin bisidder, sekretær 
Kirchberg fra Flensborg, for kredsudvalget. De omtalte, at det i svendeherberget både var billigt, og svendene dér havde en bedre moralsk holdning. Erichsen selv var en agtværdig person, der havde været soldat, og som lavsmæssig svend havde han $i$ over tre år arbejdet hos samme mester. Lokalerne i Slotsgade så ganske vist slette ud, men han agtede at modernisere dem. Året før havde der overnattet mere end 2000 svende, og man troede ikke, at Zur Heimat kunne tage alle vandrende svende. Politimester Rickmers svarede, at tallene netop viste, at magistratens og politiets opfattelse var rigtig, for i Zur Heimat kunne der optages 20 svende ad gangen. "Herbergsvater" Sommer sørgede for orden og tugt, så det måtte afgjort afvises, at der var behov for Luppis herberg. Kredsudvalget besluttede ikke overraskende at afvise Erichsens klage med henvisning til, at der ikke var behov for en fortsættelse af Luppis herberg.

Erichsen fortsatte kampen ved at indanke dommen for distriktsudvalget $\mathrm{i}$ Slesvig. Udover de tidligere argumenter fremførte han, at det efter hans mening var et brud på næringslovgivningen, når et yngre foretagende som Zur Heimat blev fremmet på bekostning af et gammelt som Luppis. Det var indgreb i håndværkernes velfærdsindretninger, hvis de blev frataget herberget, der var deres eget valgte hjem. Anken ledsagedes af petitionen, som ifølge Erichsen var underskrevet af flere hundrede borgere. Politiets moderklæring fastholdt derimod, at Zur Heimat var stort nok til at huse alle de rejsende svende. Luppis herberg blev nedsættende omtalt og det kristelige rosende. Fagforeningernes behov for forsamlingslokaler mente Rickmers kunne dækkes af beværtninger, som fandtes $i$ stort antal i byen. Det viste ifølge politiet ikke noget behov, når ansøgningen var støttet af 181 svende, ikke flere hundrede borgere som anfort af Erichsen. Desuden havde et herberg Zur Heimat i mange andre byer afløst et andet herberg, f.eks. i Sønderborg, Tønder, Plön, Ratzeburg og Løgumkloster.

$\mathrm{Nu}$ greb landråd von Uslar direkte ind for at sikre udfaldet af sagen. Han pålagde den 12.juni 1902 politiet i h.t. udførelsesforordningen angående Næringsloven at fremskaffe tegninger og beskrivelser af de rum, som skulle anvendes til svendeherberget i Slotsgade. Han spurgte senere, om de fremsendte tegninger virkelig svarede til virkeligheden. Åbenbart ville von Uslar via bygningslovgivningen sikre sig imod, at herberget alligevel skulle blive godkendt ved den højere instans. Rickmers svarede, at målene på næsten alle rum ikke svarede til virkeligheden. Efter byggeopsynsmand Flindts mening var bygningen i øvrigt så brøstfældig, at den næppe tålte større ændringer.

Selve sagen kunne landråden også påvirke. Den 8.august 1902 skrev von Uslar på eget initiativ til regeringspræsidenten, der var formand for distriktsudvalget, hvor den endelige afgørelse skulle træffes. Han oplyste, at Erichsen 


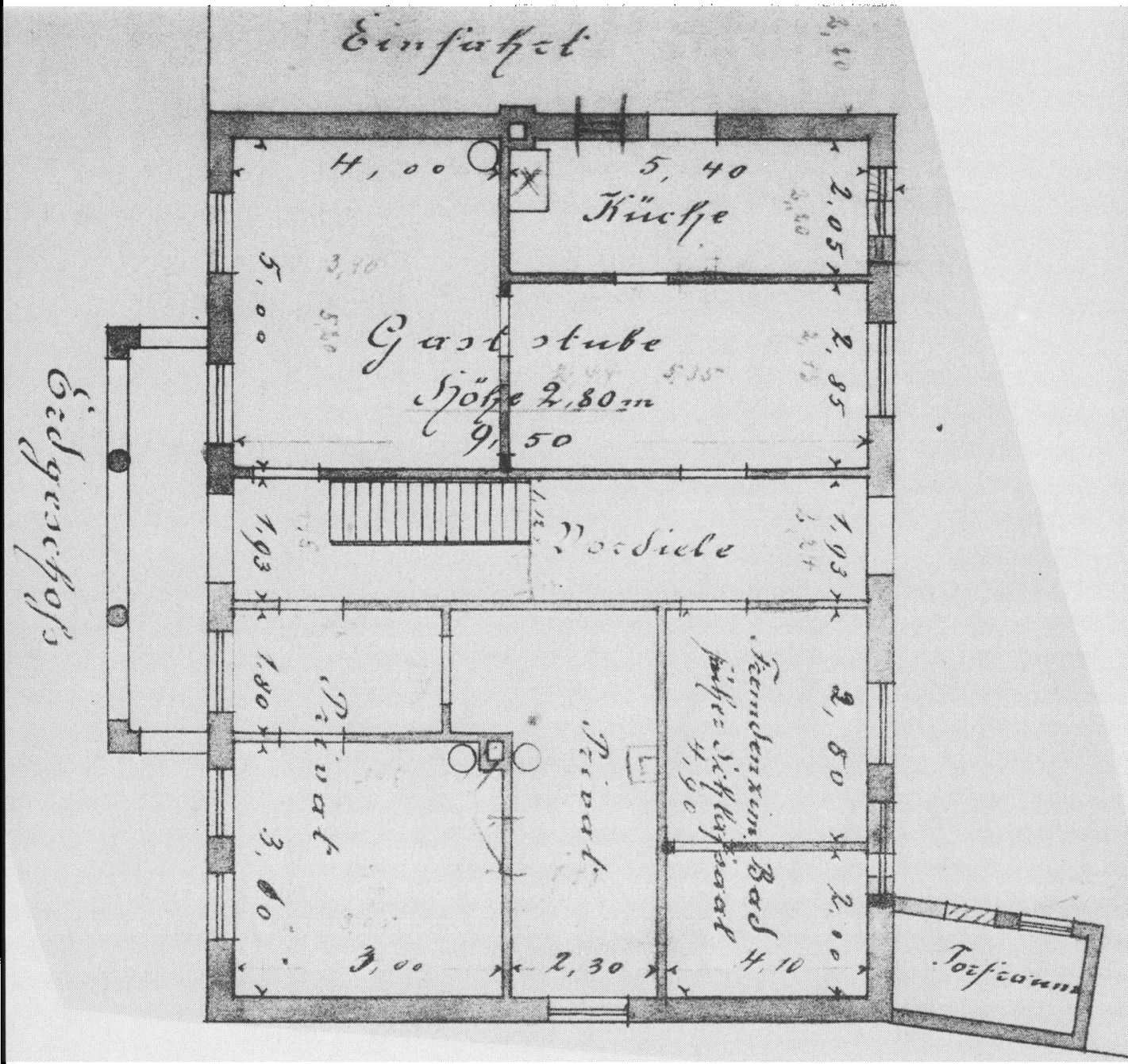

En af Hans Christian Erichsens tegninger af svendeherberget. På tegningen har myndighederne korrigeret målene. (Aab. kr. Verwaltungsstreitsache des Tischlers Hans Christian Erichsen, ... wegen Versagung der Erlaubnis der Herbergswirtschaft in Apenrade 1902 (lb. nr. 156)).

havde appelleret sagen, og at den ville blive fremsendt om få dage. Og han bad regeringspræsidenten om velvilligt at virke for, at Erichsen ikke fik bevillingen. Herberget var nemlig en socialdemokratisk restauration, hvor der blev bedrevet meget politik. Desuden var lokalerne ganske utilstrækkelige. Bygningen selv lå nærmest for enden af en meget benyttet gade, men som ikke godt 
kunne passeres om vinteren, især af damerne, fordi der tit tumlede fordrukkent pak af enhver slags omkring!

På den baggrund kan det ikke undre, at distriktsudvalgets dom bekræftede, at Erichsens begrundelser på ingen måde var egnede til at påvise behovet for et herbergsgæstgiveri ${ }^{71}$.

Efter enken Luppis død havde sønnen Robert haft en midlertidig tilladelse til at drive restauration og herberg frem til 1904, hvor hans søskende blev myndige. Da arvesagen sluttede 1903, tilfaldt herberget ham, og han søgte naturligvis om bevilling til også at måtte drive det. Ikke overraskende blev ansøgningen afvist af magistraten i Aabenraa. Den 9.juli 1903 mødte Robert Luppi selv op hos landråd von Uslar med tegninger til en nybygning af herberget under armen. Det satte skub i landråden, der endnu samme dag meddelte politiet, at i h.t. kompetencelovens $\S 114$ om høring af lokalpolitiet i gæstgiverbevillingssager skulle der gøres indsigelse imod bevillingen. Landråden fik det ønskede svar, og i begyndelsen af september 1903 afviste kredsudvalget også ansøgningen.

Robert Luppi ville have afslaget behandlet ved en forvaltningsretstrætte $i$ kredsudvalget, og da von Uslar åbenbart ikke var ganske sikker på sagens udfald, bad han politiet om at udtale sig om herbergsværelserne svarede til dets krav. Der kunne eventuelt indsendes en betænkning om, at herberget ikke kunne få bevillingen på grund af de mangelfulde værelser. Politimester Rickmers besvarede denne henstilling ved at vedlægge en udtalelse af lederen af det konkurrerende Zur Heimat, hvori denne priste sit eget foretagende, der både havde moderne faciliteter med elektricitet, og wc'er, og hvor han var villig til at stille sin forsamlingssal til rådighed for fagforeningerne. Rickmers konkluderede, at der efter ombygningen var 62 pladser i Zur Heimat og derfor ikke behov for Luppis herberg, men det var anbefalelsesværdigt at vente 2-3 uger med lukningen, til Zur Heimat var helt færdigt med moderniseringen. Det tilsluttede von Uslar sig.

Den aabenraaske fagbevægelse foretrak bestemt Luppis herberg. Den 13. september 1903 holdt Fællesorganisationen møde for at drøfte lokaleproblemet. Argumenterne gik nu som før på, at fagforeningerne havde pligt til at sikre deres rejsende kolleger logi, og at Zur Heimat ikke kunne klare det, hvorimod personen Luppi ikke var afgørende i denne sag. Man besluttede at lade de enkelte fagforeninger indsende en petition til Aabenraa kredsudvalg om at give herberget en bevilling. von Uslar og kredsudvalget modtog arbejdernes petition, men lagde den i øvrigt blot til side.

Lige så lidt virkning havde Luppis forvaltningsretstrætte i kredsudvalget. Den blev forelagt af advokat Liedke fra Flensborg i mødet den 20.oktober 1903. Behovet for dette herberg blev endnu engang afvist. Endnu samme dag 
opfordrede politiet Robert Luppi til at lukke herberget ved ugens slutning. von Uslar havde dermed nået målet, at lukke svendeherberget, men det egentlige endemål, at begrænse den socialdemokratiske aktivitet, lykkedes dog ikke med denne aktion. Socialdemokraterne fortsatte nogen tid med at samles i den bagved liggende bygning og ellers på Folkehjem ${ }^{72}$.

\section{Kampen imod sygekassebestyrelsen}

Det var ikke kun i de første år efter århundredskiftet, at von Uslar bekæmpede socialdemokraterne. I det følgende er tiden rykket frem til 1910, halvandet år efter at han var kommet hjem fra sit lange ophold i det tørre Sydvestafrika. Det begyndte med, at den lokale sygekasse (»Ortskrankenkasse«) i Aabenraa ansatte cigarhandler og kolportør Nis Toft, der var en kendt socialdemokrat, som regnskabsfører fra den 1.april 1910. Valget var åbenbart sket på den måde, at to af bestyrelsesmedlemmerne var trådt udenfor, fordi de selv havde søgt stillingen, og af de resterende fire medlemmer havde tre stemt for Toft og en imod.

De aabenraaske arbejdsgivere havde tilsyneladende ikke kunnet få deres synspunkter ført igennem ved valget af regnskabsfører, og de var grumme utilfredse med, at det skulle være Nis Toft. Den aabenraaske arbejdsgiverforenings formand, senator Voetmann, klagede derfor den 26.marts 1910 til landråd von Uslar, der var sygekassens tilsynsmyndighed, for at få ham til at skride ind. Voetmann mente, at valgmåden og regnskabsførerens kaution var kritisabel. Det var en tilsløret sigtelse mod Tofts økonomiske forhold, idet han bad om, at sygekassens regnskaber måtte blive revideret efter en måned, for så ville arbejdsgivernes betænkelighed sikkert vise sig berettiget ${ }^{73}$

I stedet for at tage den konkrete beskyldning imod valgmåden og kautionen op, valgte von Uslar at angribe Nis Toft som påstået ikke-preussisk statsborger. Baggrunden herfor var, at han siden 1902 havde forsøgt at få stemplet Nis Toft som søn af en optant, dvs. en slesviger der i 1867 havde frasagt sig preussisk statsborgerskab. Nis Toft havde stædigt benægtet at det forholdt sig sådan, og myndighederne havde svært ved at bevise det. Efter den dansktyske optanttraktat 1907 var det sikkert von Uslar, der forhindrede at Tofts preussiske statsborgerskab blev officielt anerkendt. Den 26.november 1910, da landrådens fejde med sygekassebestyrelsen netop var endt, skrev han til regeringspræsidenten om Toft: »... en ivrig leder af det lokale socialdemokratiske parti og en meget aktiv agitator. Han er også kraftigt dansksindet. ... Anerkendelsen af hans påståede preussiske statsborgerskab er ud fra den politiske interesse absolut uønsket. ( $^{74}$

Efter senator Voetmanns henvendelse skrev von Uslar til sygekassens bestyrelse, at Toft ikke var tysk statsborger. Han påstod, at sygekassens ansatte 


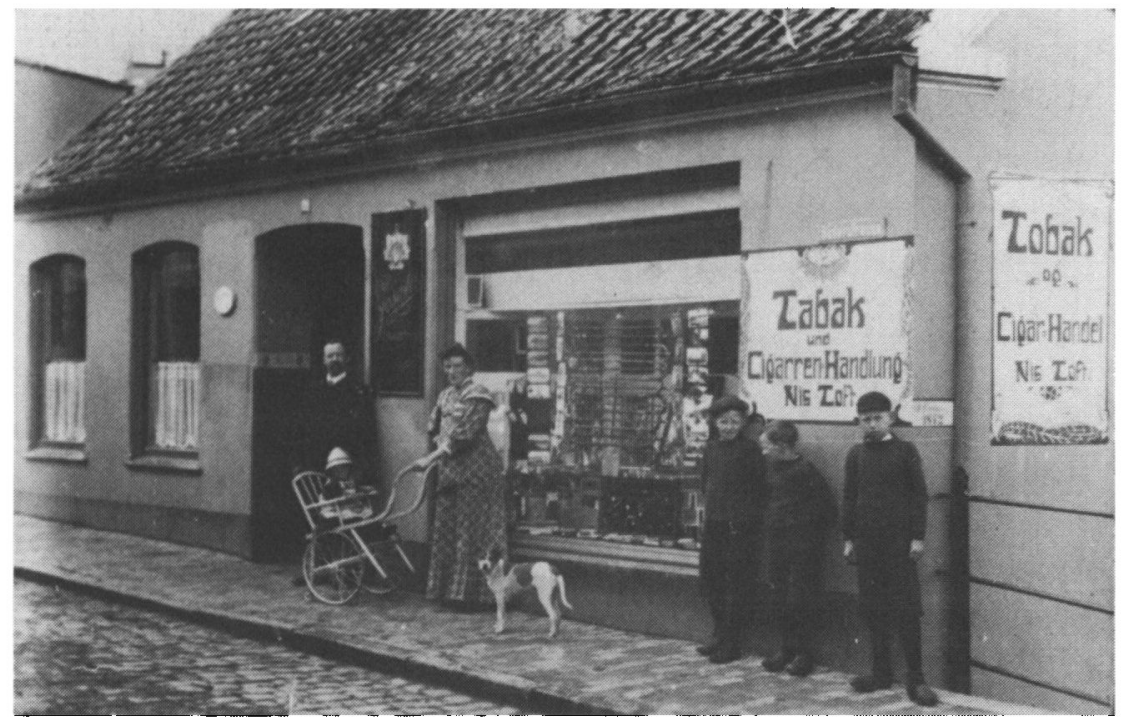

Sygekassens regnskabsforer, cigarhandler og kolportor Nis Toft er fotograferet foran sin forretning $i$ Sondergade 21 sammen med hustru og senner. Den yngste. Jorgen, sidder $i$ vognen. Billedet er fra ca. 1906. Historiske Samlinger.

("Beamte «) var en slags offentlige, betroede personer, som måtte være tyske statsborgere. Han begrundede det med, at ifølge sygekasseloven kunne straffede personer ikke beklæde sygekasseembeder, og tilsynet (dvs. landråden) kunne kræve dem fjernet. Uden at det udtrykkelig stod i loven (!) måtte de statsretslige krav om indfødsret ligeledes galde. Valget af Toft var derfor ikke gyldigt, og landråden anmodede bestyrelsen om at vælge en ny regnskabsfører.

Landrådens indgriben var klart politisk motiveret. Han sendte en kopi af sin skrivelse til arbejdsgiverne til orientering. Heri tilføjede han, at landråden ikke havde retten til at konfirmere valgene i sygekassen, men kun kunne kræve de lovmæssige forskrifter overholdt. Derfor måtte arbejdsgiverne selv være mere aktive $i$ sygekassen for at hindre lignende hændelser i fremtiden. Efter valget 1911 konstaterede han dog, at sygekassen næsten helt var i socialdemokraternes hænder.

Bestyrelsen var dog ikke til sinds at give efter for landrådens krav. Formanden, sadelmager Rosenvold svarede, at man ikke ville afskedige Toft, for kravet om afskedigelse kunne ikke støttes på nogensomhelst bestemmelser. I Rosenvolds formulering "at afskedige « lå der allerede en afvisning af, at det skulle have været et ugyldigt valg. Selv hvis Toft ikke var tysk statsborger, så var der dog ikke grund til at afskedige ham. Landråden tog fejl, når han antog, at posten som regnskabsfører var et offentligt embede. Landråden 
kunne som sygekassetilsyn nok afsætte den valgte bestyrelse, men regnskabsføreren hørte ikke til den, for han var ansat af og ansvarlig over for bestyrelsen. Bestyrelsen var på sin side den udadvendte, offentligretlige repræsentation af sygekassen.

Det fremgår af von Uslars koncepter, at han vidste, at han nu vovede sig ind $i$ et farligt område. Den 13.april 1910 truede han bestyrelsen med en bøde på 100 mark, hvis den ikke i løbet af to uger fratog Toft hvervet og valgte en anden regnskabsfører. Ellers ville von Uslar gennemføre det uden om bestyrelsen, hvis hans krav ikke blev efterkommet. Det skulle ske nu, for det kunne tage måneder, hvis sygekassen brugte sin ret til at føre en forvaltningsretstrætte til distriktsudvalget.

Bestyrelsen ville dog ikke bøje sig og indgav en klage som forvaltningsretstrætte. Men over for landråden udtrykte den i en forholdsvis ydmyg tone, at man ikke uden betydelig skade for sygekassen kunne fratage Toft arbejdet, for han havde tre måneders opsigelse. Rosenvold bad derfor von Uslar om at afvente udfaldet af forvaltningsretstrætten. Det var von Uslar ikke villig til, for et betalingsspørgsmål kunne ikke være nogen hindring. Den 7.maj truede han med en ny bøde på 100 mark, eventuelt fulgt af yderligere en bøde i denne størrelse, hvis der ikke blev valgt en ny regnskabsfører. Samtidig pålagde han regnskabsføreren for Aabenraa kredskasse (dvs. den preussiske amtstue), König, at overtage sygekassens regnskabsbøger, der befandt sig i Tofts hjem. Og ville bestyrelsen ikke samarbejde med König, skulle han, von Uslar, nok overtage dens opgaver.

Så gav bestyrelsen sig, - delvist. König fik overdraget regnskabsføringen, og man betalte ham samme løn som Toft, men man ville ikke afskedige denne. I øvrigt begyndte bestyrelsen en ny forvaltningsretstrætte over den pålagte bøde og truslen om yderligere bøder.

På dette tidspunkt burde von Uslar have indset, at han var på vej til at lide et nederlag. Regeringspræsident Ukert havde nemlig tilsendt ham sygekassens forste klage til udtalelse med den kommentar, at hvis oplysningerne deri var rigtige, skulle von Uslars anordning mod sygekassen straks trækkes tilbage. Tilsynsmyndigheden havde ikke kompetence til at skride ind over for forretningsføreren og ansætte en anden. Bestyrelsesmedlemmer kunne fratages deres hverv, men det var der ikke tale om her. Regnskabsførerens stilling hvilede på en ansættelsesaftale.

Disse synspunkter svarede til sygekassebestyrelsens, hvad der burde have vejet tungt $i$ landrådens vurdering, for regeringspræsidenten var formand for distriktsudvalget, der skulle dømme i sagen. von Uslar havde ikke ringe tanker om sig selv, for han mente, at fremstillingen var forkert og sendte sin medarbejder, regeringsassessor dr.Coester til Slesvig for at forklare sit 
synspunkt over for regeringspræsidenten. I følge von Uslars notat fik dr.Coester regeringspræsidentens tilslutning til, at anordningen ikke skulle trækkes tilbage. Det skulle senere vise sig, at sådan havde regeringspræsidenten ikke forstået samtalen.

Regeringspræsident Ukert havde også ønsket von Uslars kommentar til de to klager fra sygekassebestyrelsen. Landråden svarede med en henvisning til, at Toft var en statsløs optantsøn. Derfor ønskede han, at regeringspræsidenten afviste klagen med henvisning til en afgørelse ved Overforvaltningsretten. Med hensyn til sit krav om ny forretningsfører hævdede von Uslar, at der kunne anvendes "... enhver gældende retssætning, om udtalt eller uudtalt«. Udover de strafferetlige forhold kunne der også være statsretlige forhold, der gjorde en person uegnet til at beklæde et offentligt embede. " "... Ret fundet ved udledning kan meget vel være gældende ret, også selv om det ikke udtrykkelig står i nogen lov." ("Solches auf dem Wege der Ableitung gefundene Recht kann sehr wohl geltendes Recht sein, auch wenn es in keinem Gesetz expressis verbis steht $«$ ).

På denne redegørelse svarede regeringspræsidenten, at han anså von Uslars begrundelser for helt forfejlede, og at ophævelsen af dennes anordninger sikkert var forstående, men han ville ikke hindre landråden i at få en afgørelse ved en forvaltningsretstrætte ved distriktsudvalget. Efter von Uslars mening var sygekassens skarpe klager udformet af det socialdemokratiske arbejdersekretariat i Kiel, og vist er det, at de virker professionelle i formen sammenlignet med sadelmager Rosenvolds indlæg. Det kan næppe bevises, at klagerne er udformede i Kiel, men landrådens henvisning dertil viser, at han opfattede denne strid som en kamp mod socialdemokraterne.

Sygekassen og landråden sendte nu deres skriftlige indlæg til distriktsudvalget med gentagelser af deres kendte argumenter. Den 19.september 1910 afsagde distriktsudvalget under forsæde af regeringspræsident Ukert sin dom, og den gik klart landråden imod. Hans anordninger af 13.april og 7.maj 1910 blev ophævede, og som taber skulle han naturligvis betale sagsomkostningerne. Distriktsudvalget fulgte sygekassens påstande med undtagelse af et enkelt forhold, nemlig at tilsynsmyndigheden også havde ret til at afsætte regnskabsføreren, hvis der var grund til det. Der skulle i sygekasselovgivningen være anført, hvad der kunne begrunde afsættelsen, og dér stod intet om statsborgerskab. Distriktsudvalget tilføjede endda, at selv bestyrelsesmedlemmer i en sygekasse ikke behøvede at være tyske statsborgere.

von Uslar var naturligvis ikke tilfreds med dette resultat, men han mente dog, at hans opfattelse kun var blevet forkastet af distriktsudvalget, men ikke modbevist! Før han besluttede sig til at anke dommen til Overforvaltningsretten i Berlin, ville han dog forhøre sig i »Verband der deutschen gemeinnützigen 
und unparteiischen Rechtsauskunftsstellen «, om der andetsteds havde været en tilsvarende retssag, og om man mente, at sagen kunne vindes ved at blive anket. Dette "Verband" var en sammenslutning, som von Uslar kort forinden havde ladet Aabenraa kredsudvalg blive medlem af, og hvis formål det var at yde gratis retshjælp til de mindrebemidlede befolkningsklasser, særlig på det socialpolitiske område ${ }^{75}$. Svaret var nej. Man havde set efter i Reichsversicherungsamts bibliotek, men hverken i lovkommentarer eller i domme fandtes støtte til von Uslars synspunkt. Den sociale lovgivning på dette område skelnede ikke mellem tyskere og udlændinge, og man kunne derfor ikke dele landrådens opfattelse. Først nu opgav von Uslar at anke sagen, men han beholdt sikkert troen på, at han havde ret.

\section{Efterspillet: v. Uslars nederlag}

Det efterspil, som fulgte efter von Uslars nederlag ved distriktsudvalget, varede næsten til hans afgang som landråd, og det gav anledning til nogle sagkyndige vurderinger af hans dømmekraft.

Den 12.oktober 1910 gav dr. Coester på landrådens vegne sygekassen dens bøger og pengekasse tilbage. Sygekassen havde kun båret omkostningerne ved den midlertidige forvaltning under König med forbehold af regres, altså at blive holdt skadesløs for udgifterne. $\mathrm{Nu}$ kom netop den økonomiske side af sagen i centrum. Fra tre sider var der krav til von Uslar om penge. Distriktsudvalget ville have nogle få mark i portoudlæg. Sygekassen krævede derimod 673,50 mark til dækning af løn til den midlertidige forretningsfører König, til avisbekendtgørelser, spildtid for tre bestyrelsesmedlemmer samt porto. Endelig var der König selv, der havde måttet ansætte et bud for at indsamle de ugentlige bidrag til sygekassen, hvorved han kun havde fåt det ringe beløb af 43 mark ud af at forvalte sygekassens regnskaber $i$ fem måneder. Han mente, at indsatsen havde været $i$ hvert fald 350 mark værd og bad derfor von Uslar om at måtte få differencen. Alt $\mathrm{i}$ alt var der krav på 983 mark til landråden.

von Uslar sendte regningen til regeringspræsidenten med anmodning om at statskassen ville betale, da han havde udstedt sine anordninger som organ for landspolitimyndigheden. Regeringspræsidenten henviste sagen til distriktsudvalget, der dog kun ville se bort fra sit eget krav og senere også var villig til at dække sygekassens portoudgifter på 6,80 mark. Mere ville man ikke betale.

König ses ikke at have gjort mere for at gennemføre sit krav om en ekstrabetaling på 307 mark. Det havde nok også været ret svært. Sygekassen havde derimod indhentet et responsum på, om den skulle fortsætte sagen mod landråden. Det blev sygekassen tilrådet at gøre ${ }^{76}$. Sygekassen anlagde nu civilt søgsmål ved Landsretten i Flensborg for at få de mange hundrede mark hjem. 
Sygekassens advokater Christians og Leonhardi krævede statskassen dømt til at betale 666 mark samt renter, fordi landråden ved forsømmelig embedsførelse havde pådraget sygekassen denne udgift. På modpartens side havde regeringspræsidenten pålagt statens advokat Scheel at fastholde, at von Uslar kun havde befundet sig $i$ en undskyldelig retsvildfarelse (»Rechtsirrtum «), idet han nøje havde gennemgået sagen, før han havde udstedt sine anordninger. Denne opfattelse fremsatte regeringspræsident Ukert dog snarere af hensyn til pengene end ud fra nogen dyb overbevisning. Når der ikke var tale om forsømmelighed, bortfaldt statens pligt til at hæfte for udgifterne, mente han. Med denne indfaldsvinkel kom processen også til at belyse, hvad betydende preussiske jurister mente om landråd von Uslars administrative formåen i denne sag.

Efter ønske fra regeringen i Slesvig blev processen ved Landsretten standset den 16. november 1911 og indbragt for Overforvaltningsretten, der skulle afgøre spørgsmålet, om det var forsømmelighed eller en undskyldelig retsvildfarelse. Næsten et år senere afsagde Overforvaltningsretten sin dom.

Regeringens advokat henviste $i$ sit indlæg til Overforvaltningsretten til en tidligere dom ved denne ret, hvor der var skelnet mellem en grundig, men fejlagtig retsoverbevisning og en forsømmelig embedsførelse. Landrådens udforlige begrundelse for sin anordning af 13.april 1910 viste, at han havde gennemgået sagen grundigt. I modsætning hertil hævdede sygekassens advokater, at von Uslars anordninger ikke kun var objektivt urigtige, men også beroede på forsømmelighed. I kraft af sin stilling burde han vide, at lovens udtrykkelige begrænsninger ikke kunne tilsidesættes ved en udvidende fortolkning, som han havde gjort.

Overforvaltningsretten fik også forelagt et responsum fra Landsretten i Flensborg til Justitsministeren. Heri hed det bl.a., at det måtte komme landråden til skade, at han havde overskredet sine embedsbeføjelser. Sygekasselovens $\S 42$ anførte nemlig udtømmende, hvornår tilsynsmyndigheden kunne fratage bestyrelsesmedlemmer eller en forretningsforer embedet, og formuleringen kunne ikke misforstås. Overlandsretten i Kiel var ligeledes blevet hørt, og den mente, at von Uslars udlægning af sagen ikke kunne være sket uden forsømmelighed fra hans side som embedsmand.

I sin dom den 17.september 1912 slog Overforvaltningsretten fast, at sygekassens omkostninger burde dækkes af myndighederne, uanset om der måtte foreligge en undskyldelig retsvildfarelse. Men det mente retten ikke var tilfældet, og man formulerede følgende krasse kritik af von Uslar: "... I det foreliggende tilfælde kan det ikke anerkendes, at landråden ved en pligtmæssig overvejelse skulle komme til den opfattelse, at tysk statsborgerskab (»Reichsangehörigkeit () skulle være den lovlige forudsætning for ansættelsen som regnskabsfører for den lokale sygekasse... Altså har landråden ikke anvendt 
den overvejelse, som man måtte forvente af ham som højere forvaltningsembedsmand ved anvendelsen og udlægningen af lovene. Da hans embedshandling også er objektivt utilladelig og ikke finder støtte i § 45 i Sygeforsikringsloven, har han overskredet sine embedsmæssige beføjelser...«.

Statskassen måtte nu betale regningen for von Uslars sygekassefejde, og den blev opgjort til 892,72 mark. Det vakte bestemt ikke begejstring hos landrådens foresatte. Af et brev fra indenrigsministeren i Berlin til regeringspræsidenten i Slesvig fremgår, at man udmærket var klar over, hvorfor von Uslar havde handlet på den måde i foråret 1910. Man havde også forståelse for, at von Uslar i overdreven iver ud fra politiske motiver havde brugt tvangsanordninger. Men indenrigsministeren påpegede, at von Uslar to gange havde ønsket at fortsætte sagen, uagtet at regeringspræsident Ukert havde gjort ham opmærksom på, at hans begrundelser var forfejlede osv. Man kunne ikke frikende von Uslar for skyld i de vesentligt øgede omkostninger, og efter kontakt med den preussiske finansminister mente indenrigsministeren, at staten havde krav på hel eller delvis tilbagebetaling fra landråden.

von Uslar havde meget lidt lyst til at betale. Han svarede den 12.juni 1913 regeringspræsidenten, at han ikke var $i$ stand til at betale. Det var sikkert rigtigt, at han havde en meget dårlig økonomi" . Om han betalte noget af regningen her $\mathrm{i}$ de sidste måneder, for han gik af som landråd, fremgår ikke og er heller ikke væsentligt. Men det var typisk for ham, at han til det sidste prøvede at vise, at han alligevel havde ret. Regeringspræsidenten havde nævnt, hvad dr. Coester i 1910 havde sagt på von Uslars vegne. Heroverfor indhentede von Uslar nu en fyldig redegørelse fra dr.Coester, der blev videresendt til regeringspræsidenten. Og von Uslar prøvede også at retfærdiggøre sine handlinger på anden måde, nemlig ved at henvise til den seneste ændring af sygekasselovgivningen, hvorefter kun tyskere havde ret til at beklæde hverv i sygekasserne. Denne lovændring havde været under forberedelse, og han så deri en anerkendelse af den bestående ret. Underforstået var, at så havde han alligevel haft ret. Men regeringspræsidenten svarede ganske kort, at den ny bestemmelse gjaldt bestyrelseshverv, ikke ansatte, - som von Uslar mente!

Fejden med bestyrelsen for sygekassen i Aabenraa for at ramme socialdemokraterne viser måske mest detaljeret, hvordan von Uslar var som landråd $\mathrm{i}$ en problematisk situation. Hans kendskab til sygekasselovgivningen m.m. var overfladisk, men han prøvede at klare sig igennem med urimelige analogislutninger. Han evnede til det sidste ikke at skelne mellem begreberne "valgte repræsentanter« og "ansatte«, og trods flere henstillinger fra sin overordnede, regeringspræsidenten, fulgte han stædigt sin egen kurs. 


\section{Konklusion og afslutning}

Det er ikke let at give en vurdering af en embedsmands personlighed. I denne fremstilling af von Uslar er det sket på grundlag af nogle politiske konflikter, hvor kanterne af hans personlighed er trådt klarere frem. Der er ingen tvivl om, at han netop tillagde det politiske indhold af sin stilling en meget afgørende betydning. Han pointerede 1910 over for politimester Rickmers: »... Da jeg som repræsentant for den kongelige regering her på stedet må være rettidig orienteret om alle vigtigere tildragelser, sarlig $i$ politisk henseende, for eventuelt endnu rettidigt at kunne give anvisninger, henviser jeg hermed endnu engang udtrykkelig politiforvaltningen, til i fremtiden straks at melde mig alle påtænkte foranstaltninger af politisk art og ved tildeling af tilladelser ... på forhånd at indhente mit samtykke. ${ }^{78}$ Fremhævningerne er von Uslars egne.

I begyndelsen af artiklen skitseredes to forskellige syn på von Uslar. Sievers mente, at landråden var en dygtig og velset amator, der viste en modereret embedsførelse, uden hensynsløs skarphed og båret af et godt forhold til befolkningen. H.P.Hanssen gav derimod allerede i samtiden udtryk for, at landråden havde overfladiske kundskaber, og i stedet arbejdede med en fremtrædende iver og med uetiske midler. Sagerne mod de dansksindede og socialdemokraterne drejer sig om nogle mindre kendte forhold end $»$ tjenestedrengekrig«, "Saalabtreiberei« og udvisninger, men de peger tydeligt på H.P.Hanssens vurdering som den rigtige.

I løbet af sin landrådstid deltog von Uslar i landrådskonferencer med fagligt indhold og et kort statsvidenskabeligt efteruddannelseskursus ${ }^{74}$. Han fik også medarbejdere tildelt, så der ved siden af ham fungerede en kredssekretær, en assessor og en assistent. Alligevel viser sagerne flere gange mangel på elementært kendskab til lovene, f.eks. til indforelse af den ny borgerlige lovbog, bygningspolitiordningen, sygekasselovgivningen, eller til Kammerrettens seneste domme. For at nå det politiske mål anvendte han gerne andre love end de relevante. Det var en metode, som de fremtrædende jurister i Overforvaltningsretten ikke lod sig forlede til at anvende ${ }^{80}$. Åbenbart mente von Uslar, at man kunne slutte analogt mellem forskellige juridiske bestemmelser uden at sikre sig at forudsætningerne herfor var til stede. En landråd med en juridisk uddannelse ville nok have været mere varsom med at bevæge sig ud i dette farlige område. At von Uslars evne til at skelne mellem begreber ikke var meget udviklet, synes at fremgå af, at han til det sidste ikke forstod forskellen mellem ansatte og bestyrelsesmedlemmer i en sygekasse. En domstol betegnede hans fremstilling i netop denne sag som forsømmelig, hvorimod Overforvaltningsretten skrev, at der ikke var anvendt den overvejelse, som man måtte forvente af en embedsmand ved fortolkningen af love. I den konkrete sag lå domstolenes vurdering ikke langt fra H.P.Hanssens. 
von Uslar var i de politiske sager fyldt med iver og energi. Og var retsgrundlaget for en aktion ikke til stede, så pegede han allerede før von Köllers tid over for sine overordnede på at få ændret grundlaget. I tiden efter von Köller lagde de højere embedsmænd i Slesvig efterhånden en mere moderat linje, men von Uslar fortsatte endnu 1910 med iver den skarpe linje. Over for den underordnede politimyndighed i Aabenraa, politimester Rickmers fremsatte landråden flere gange skarpe henstillinger om en mere aktiv indsats både over for dansksindede og socialdemokrater ${ }^{81}$.

I de gengivne politiske sager er der også træk, som vidner om det H.P.Hanssen kaldte en voldspolitik uden etisk grundlag. Det gælder, når man ser landråden på den ene side foretage hemmelige aktioner mod Fællesorganisationen, og på den anden side lade neutral og uden indflydelse, når arbejderne henvendte sig til ham. For en moderne betragtning virker det på samme måde, når man ser landråden pålægge politimesteren at give afslag, samtidig med at han beder denne om at give den lovpligtige sagkyndige erklæring, før der blev tildelt koncession til gæstgiveri e.l.

Det er nok tvivlsomt om den administrative virksomhed havde von Uslars egentlige interesse. Han brugte også en del af sin tid på militære øvelser og avancerede efterhånden til ritmester. Nogen tid brugte han på møder $\mathrm{i}$ »Landwirtschaftskammer« og på rejser for at søge efter vand. I sig havde han nok en uro, som medførte, at han måtte ud og opleve noget det ene og det andet sted. I 1897 fik han gennem admiral Knorr kontakt med kejser Wilhelm II og derved den allerhøjeste forståelse for sin trang til at lære de tyske kolonier at kende og udvide sine almindelige kundskaber. Det blev til en orlov med Hs. Majestæts skib »Nixe« til Kamerun i knap 8 måneder fra 7.august 1897 til 23. marts 1898. von Uslar meddelte selv regeringspræsident Zimmermann, at det forholdt sig således og bad om at måtte beholde sin $l ø n^{82}$. Det er svært at forestille sig, at denne »uddannelsesrejse« med løn og arrangeret uden om de sædvanlige kanaler har vakt begejstring hos von Uslars foresatte i Slesvig ${ }^{83}$.

Efter at han var kommet hjem igen, havde han i de følgende år mange små fravær, og i 1905 førte det til en henstilling fra regeringspræsident von Koszierowski om at holde inde. Med udgangen af juli 1905 havde von Uslar været fraværende fra tjenesten i 73 dage, hvortil nu kom en orlov i 28 dage og en militærøvelse i oktober. Den sidste måtte falde bort, mente regeringspræsidenten.

Få måneder efter fik regeringspræsidenten meddelelse fra indenrigsminister von Bethmann Holweg om, at han foreløbig for et år havde stillet landråden til rådighed for udenrigsministeriet til anvendelse i kolonierne. Fraværet varede fra udgangen af januar 1906 til oktober 1908, altså i mere end $2 \frac{1}{2}$ år, hvor von Uslar var i det tørre Tysk Sydvestafrika og efter sigende fandt vand. 


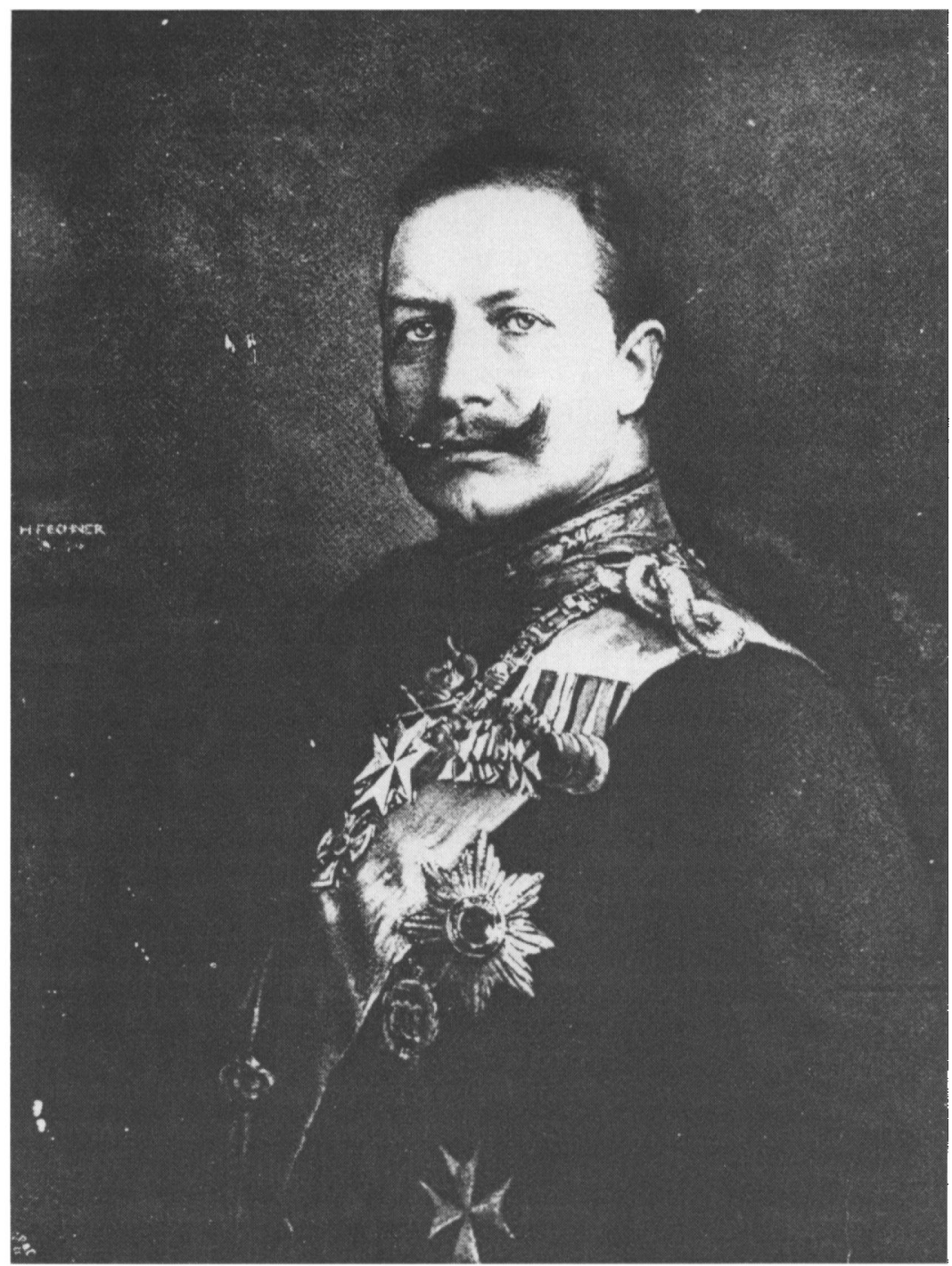

Von Uslars kejserlige beskytter Wilhelm II. Dette billede af den ordenssmykkede kejser blev benyttet til udsmykning $i$ utallige skoler. Gravure i Aabenraa kredsudvalgsarkiv B II.

Inden han genoptog landrådsfunktionen, var han i øvrigt hos sin kejser for at aflægge beretning om forholdene derude ${ }^{84}$.

I 1908 fik han også tid til at søge efter petroleum i nærheden af Hannover. Den håbefulde landråd benyttede hertil en onskekvist af en ganske speciel, hemmelig kobberlegering. Men resultatet var nok beskedent. Ministeriet lod 
senere indhente erklæringer fra videnskabsmænd, der pure afviste muligheden af, at man kunne finde olie på denne måde ${ }^{84}$.

I 1911 var landråden indlagt $\mathrm{i}$ tre måneder på sygehuset til operation af nyrerne. I efteråret 1912 meddelte han regeringspræsidenten, at hoffet telegrafisk havde bedt ham indfinde sig i Berlin for at tale om fremskaffelse af vand på øen Korfu. Derefter var han på en længere udenlandsrejse. Året efter holdt han en lang ferie i USA, hvor han bl.a. var i New York ${ }^{85}$.

Det er ikke utænkeligt, at von Uslars overordnede i Slesvig var noget trætte af hans ustadighed og hans direkte kontakter til hoffet for at fremme sin egen sag. Han var efterhånden blevet temmelig kålhøgen over for sine overordnede, og det forte til hans afgang i 1913.

Ved sin hjemkomst den 24.juli 1913 fra New York mødte der ham en sag vedrørende forflytningen af kredssekretær Ebelt til Eckernförde, hvor han ikke var enig i regeringspræsident Ukerts dispositioner. Det skrev han til overpræsident von Bülow, der var Ukerts foresatte. Ukerts kommentarer til von Uslars skrivelse var meget skarpe. Han bemærkede, at bortset fra visse politiske vanskeligheder var der ganske enkle forhold i Aabenraa kreds. Alligevel havde von Uslar fået tildelt en assessor og kredsassistent udover kredssekretæren. Det skyldtes, at landrådens ydeevne var meget begrænset, og at der gentagne gange var blevet klaget over ham. Desværre led von Uslar samtidig af en selvforgudelse (»Selbstüberhebung«), for hvilken han før eller siden måtte irettesættes. Han tålte åbenbart slet ikke, at de foresatte myndigheder bedømte forholdene anderledes end han selv. Forflytningen af kredssekretæren var sket af den enkle grund, at han led føleligt under von Uslars nervøse væremåde. Hvis von Uslars henvendelse til overpræsidenten overhovedet var tilladelig ud fra kompetencefordelingen, så ville regeringspræsidenten henstille, at landrådens indstilling til sagen blev afvist.

von Uslar søgte nu sin afsked fra statstjenesten og fik den bevilget med pension. Afgående landråder plejede at modtage en orden, men regeringspræsidenten mente, at det burde man se bort fra i dette tilfælde. Overpræsidenten forstod grundene til regeringspræsidentens indstilling, men måtte dog alligevel mene, at von Uslar skulle have en orden. Til indenrigsministeren skrev overpræsident von Bülow, at grundene ikke var offentligt kendt $i$ befolkningen, hvor man ville synes, at landrådens afgang uden en orden var påfaldende. Fra dansk side ville det blive kædet sammen med det dårlige udfald af det sidste landdagsvalg, hvilket ikke var ønskeligt. von Bülow pegede specielt på et par ordener, som let kunne opnås, da von Uslar hidtil særligt var blevet værdsat af kejseren og dennes bror ${ }^{86}$. En sådan fik landråden da.

Således gik det til, at von Uslar egentlig havde de dansksindede at takke for sin orden, da han afgik som landråd den 1.november 1913! Det foregik i 


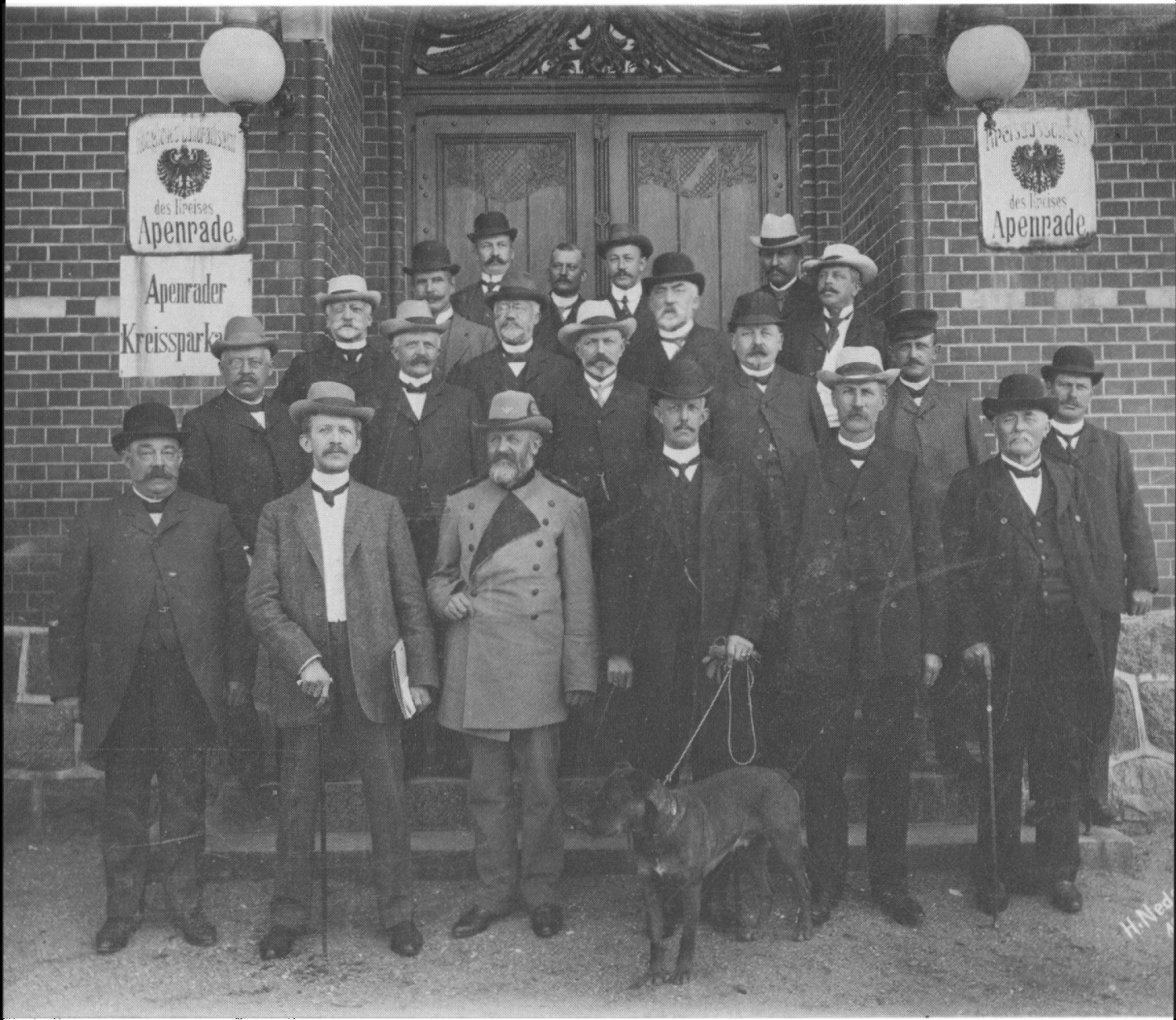

Landråd von Uslar er her fotograferet i 1909 sammen med Aabenraa kredsdag på trappen til amtshuset $i$ Aabenraa. Landräden proger hilledet, i bedste godsejerstil med hund $i$ snor. Pả billedet genkender man flere af personerne fra artiklen her. Borgmester Rickmers. Aabenraa ses som nr. 1 fra venstre $i$ nastnederste rakke. Forrelningsforer König ses med bowlerhat overst midt for venstre dor. På vaggen pranger embedsskiltene for landradskontoret, kredsudvalget og kredssparekassen. Foto i Historiske Samlinger. 
stilhed $^{87}$. Han rejste til Canada, hvor han var, da Første Verdenskrig brød ud. Her blev han kortvarigt interneret, men vendte allerede i julen 1914 hjem til Tyskland. I krigsårene forvaltede han en kort tid landrådsembederne Lennep i Westfalen og Westpriegnitz i Mark Brandenburg. Efter krigen levede han i Detmold, hvor han døde den 31.maj 193188.

\section{NOTER OG HENVISNINGER}

De anførte arkivalier findes, hvor ikke andet er angivet, i landsarkivet i Aabenraa.

\section{Forkortelser:}

LASH Landesarchiv Schleswig-Holstein, Gottorp Slot i Slesvig

SJy Aarb Sønderjyske Årbøger

Aab By Aabenraa Byarkiv

Aab kr Aabenraa kredsudvalgsarkiv

Aab ldr Aabenraa landrådsarkiv

1. Han holdt foredrag om vandsøgningen i Kiel 1909 , se Aab kr von Uslar und Club der Landwirte 1909.

2. Haandbog i det Nordslesvigske Spørgsmaals Historie. Red. af Franz v. Jessen (1901) s. $615 f$.

3. H.P. Hanssen omtalte ham også i nEt Tilbageblik « bd. IV s. $118 f$.

4. H.P. Hanssen-Nørremølle: Köllerpolitikken, Sjy Aarb 1905 s. $243 \mathrm{ff}$.

5. Kai Detlev Sievers: Die Köllerpolitik und ihr Echo in der deutschen Presse 1897-1901. Quellen und Forschungen Bd. 47 (1964) s. 56f.

6. Schleswig-Holsteinisches Biographisches Lexikon Bd. 1 (1970) s. $274 \mathrm{f}$.

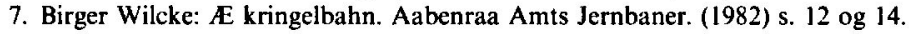

8. G. Japsen: Den fejlslagne germanisering (1983) s. 91ff, 106, 156.

9. Schleswig-Holsteinisches Biographisches Lexikon Bd. 1 (1970) s. $274 \mathrm{f}$.

10. Trap Danmark 5. udg. bd X,3 s. 979; Gråsten amtsretsarkiv grundbog Rinkenæs bd V bl 133; H.P. Hanssen: Köllerpolitikken, i Sjy Aarb 1907 s. 318; sm.: Et Tilbageblik bd. IV s. 119; Poul Andersen: Buskmose, en gård og dens ejere gennem 500 år. Årsskrift 1980 for Historisk Forening for Gråsten by og egn s. 524 .

11. H.V.Clausen: Folkesproget i Sonderjylland. I Sjy Aarb 1893 s. 91.

12. G. Japsen: Amtsforstanderinstitutionen i Nordslesvig. I Festskrift til Johan Hvidtfeldt (1978) s. 189 207; se også Aab kr. Nachweisungen der zum Amte eines Amtsvorstehers geeigneten Personen ... 1894-1920.

13. Rinkenæs amtsforstander. A gen. 4: Allgemeine Geschäftsführung; A spec. 7: Verwaltungsberichte; A gen. 1: Amtsausschuss.

14. von Bitter: Handbuch der preussischen Verwaltung. Bd. I s. 989.

15. Aab ldr. A spec. 2: Wahl und Ernennung, skr. 7/5 1901.

16. Aab ldr. A spec. 2: skr. $13 / 101892,25 / 101892,5 / 81893$.

17. Aab ldr. A spec. 2: skr. 26/11 1894, 30/11 1894, 15/12 1894; Kreisblatt 25/6 94, $17 / 111894$.

18. Aab Idr. A spec. 2: skr. 15/12 1894; Kreisblatt des Kreises Apenrade. Meddelelse 339/1894.

19. von Bitter: Handbuch der preussischen Verwaltung. Bd. II s. 20ff; Haandbog i det Nordslesvigske Spergsmaals Historie s. 517, 615 .

20. von Bitter: Handbuch der preussischen Verwaltung Bd. I s. 994.

21. M. Mackeprang: Nordslesvig 1864-1909 (1910) s. 226.

22. G. Japsen: Den fejlslagne germanisering s. $34 \mathrm{om}$ von Bonins holdning til Den tyske Forening.

23. Haandbog i det Nordslesvigske Spørgsmaals Historie. s. 560 . 
24. G. Japsen: Den fejlslagne germanisering. s. 60ff., 82.; M. Mackeprang: Nordslesvig 1864-1909. s. 225ff; H.P.Hanssens artikler i Sjy Aarb om Köllerpolitikken, specielt 1905 s. 225-232.

25. Aab ldr G spec. 2: Politische Agitationen und Demonstrationen und Uberwachung derselben 1893-1900. specielt skr. 28/8 1895, 22/11 1895, 18/10 1895 .

26. Aab ldr. A spec. 1'. Die allgemeine Geschäftsführung des Kgl. Landraths Amts (Inventarium) 1868-1899, skr. 26/11 1896.

27. Aab ldr G spec. 2: specielt skr. $25 / 111896$.

28. Aab ldr. D spec. 15: Zeitungsberichte 27/12 1898, $29 / 31899$.

29. Rinkenæs amtsforstander. G gen. 3: Socialdemokratie, Streiks. cirk.skr. 18/7 1890.

30. Oversættelserne af de tyske juridiske udtryk er taget fra H.P. Hanssens fremstilling i Haandbog i det Nordslesvigske Spørgsmaals Historie. s. 520f., hvor der også er givet en mere udførlig fremstilling af fremgangsmåden ved forvaltningstvistigheder.; Lothar Blatt: Die rechtliche Behandlung der dänischen Minderheit in Schleswig-Holstein von 1866 bis 1914 (1980). Bogen er anmeldt af Frants Thygesen i Sjy Årb 1982 s. 221-226; se også von Bitter: Handbuch der preussischen Verwaltung Bd. II s. 235.

31. von Bitter: Handbuch der Preussichen Verwaltung. Bd. I s. 642ff.; Carl Vigelius: Der Preussische Gemeindevorsteher, Amts- und Gutsvorsteher. (Leipzig 1908, 10. Aufl.) s. 26 og passim.

32. Gesetz betr. die Dienstvergehen der nicht richterlichen Beamten, die Versetzung derselben auf eine andere Stelle oder in den Ruhestand. Illing: Handbuch für Preussiche Verwaltungsbeamte, im Dienste des Staates, der Kommunalverbände, der Korporationen und für Geschäftsleute (1898, 7. Aufl. bearbeitet von Georg Kautz) s. 242ff.

33. Aab kr. Disciplinar-Untersuchung gegen den Gemeindevorsteher Chr. Jørgensen in Jolderup 1889; smstds. Disciplinar-Untersuchung gegen den Gemeindevorsteher Brodersen in Todsbüll 1890; sidstnæunte sag er refereret i Bjolderup sogns historie. Red. af Hans Vald. Gregersen og Peter Kr. Iversen (1951-56). Bd. II s. 24If.

34. Sievers, 1964 s. $56 \mathrm{f}$.

35. Kreis-Blatt des Kreises Apenrade. Meddelelse nr. 280/1897, 76/1898.

36. Aab kr. Dänisch gesinnte Gemeindebeamte 1898-1917, spec. skr. 7/2 1898; Aab kr. betr. Gemeinde Nübel 1892-1919 (lb. nr. 20j) spec. skr. 12/3 1898; Aab kr. betr. die Gemeinde Biolderup 18921919 (lb. nr. 20c) spec. skr. fra 1/8 1898-29/10 1898.

37. M. Mackeprang: Nordslesvig 1864-1909, s. 230; Sievers, 1964 s. 69 og $90 \mathrm{ff}$.

38. Aab ldr. G spec 2: skr. 15/5, 28/7 1898.

39. Aab kr. Disciplinar-Untersuchung gegen den Gemeindevorsteher Hansen in Oebening 1900-1902 (lb. nr. 253); sagen er kort refereret i Lothar Blatt anf. arb. s. 87.

40. Anders Feilberg Jørgensen: Sprogforeningen gennem 100 år (1980) s. 67.

41. Aab kr. Schweizerhalle 1900-03. (lb. nr. 6).

42. F. Stier-Somlo: Verwaltungsgesetze für Preussen (1914 2. Ausg) bd. I s. 226, bd. II s. 1547; H.C.Staack: Das Polizeiwesen. Unter besonderer Berücksichtigung der Provinz SchleswigHolstein (1898) s. 426ff; Haandbog i det Nordslesvigske Spergsmaals Historie s. 521.

43. Aab kr. Ubersichten über die Koncessionen zum Gast- und Schankwirtschaftsbetriebe und zum Kleinhandel mit Spirituosen 1882-1920: sst. Verwaltungsstreitsachen, specielt fig.: Witwe Anna Diedrichsen 1903-04 (lb. nr. 154), Lorenz Friedrich Hansen 1902-03 (lb. nr. 166), Thomas Hansen 1901-02 (lb. nr. 169), Mathias Matthiesen 1902 (lb. nr. 202), og Ludwig Nielsen 1907 (lb. nr. 210) giver indtryk af bevillingspolitikken.

44. Aab By 1864-1920. II-20-1 c: Koncessioner, Nicolai Andersen, Folkehjem.

45. Aab kr. Verwaltungsstreitsache des Pächters A. Jensen ... wegen Versagung der Erlaubnis zum Ausschank von alkoholfreien Getränken 1901 (lb. nr. 179); Emil Müller: Die Gast- und Schankwirtschafts-Polizei in Preussen (1909) s. 59f.

46. Aab kr. Schweizerhalle. 1900-03 (lb. nr. 6).

47. Aab kr. Verwaltungsstreitsache des Literaten N. Andersen ... wegen Versagung der Erlaubnis zum Ausschank von Bier und Wein im Etablissement "Folkehjem« 1903-04 (lb. nr. 131); Emil Müller: Die Gast- und Schankwirtschafts-Polizei in Preussen s. 48ff. 
48. Aab kr. Verwaltungsstreitsache des Literaten $\mathrm{N}$. Andersen ... wegen Versagung der Erlaubnis zum Ausschank von Bieren mit höchstens $2 \%$ Alkoholgehalt in dem Etablissement Folkehjem 1905 (lb. nr. 132); Emil Müller: Die Gast- und Schankwirtschafts-Polizei in Preussen s. 58, 51.

49. Aab By 1864-1920. II-20-1 c; G. Japsen: Den fejlslagne germanisering s. 106f., 156.

50. Hele dette afsnit er mere detaljeret fremstillet i Jørgen Witte: Da frimenighedskirken i Aabenraa blev bygget. I Haderslev Stiftsbog 1976 s. 56-70; Aab By 1864-1920 II-9-13: Kirchlichen Verein für Apenrade und Umgegend.

51. LASH Abt 320 Apenrade 124: Vorgänge in der Protestpartei auf kirchlichem Gebiet.

52. Aab Idr $\mathrm{H}$ spec. 6: Anstellung eines ersten zweiten und dritten Polizeidieners in Apenrade 1895-1905; Aab By 1864-1920: 1-2-7 b Wahl und Anstellung des 1. Polizeisergeanten Matzen; LASH Abt 309 nr. 12562: Die Versammlungen und Vereine des Kreises Apenrade.

53. Aab ldr. G. spec. 8: Kirchlichen Verein für Apenrade und Umgegend.

54. Aab ldr. G spec. 8; LASH Abt. 320 Apenrade nr. 124; Lothar Blatt anf. arb. 1914 s. $44 \mathrm{ff}$.

55. Aab By 1864-1920 II-9-34: die Freigemeindekirche.

56. LASH Abt 320 Apenrade nr. 31: Freigemeindekirche zu Apenrade; LASH Abt 320 Apenrade nr. 57: Kapitän C.C. Fischer und seine Ausweisung und Anton Heinrich Fischer.

57. G.Japsen: Den fejlslagne germanisering s. 82f; LASH Abt 320 Apenrade nr. 31.

58. Bau-Polizei-Ordnung für die Städte der Provinz Schleswig-Holstein, bilag til Amtsblatt 1875 efter s. 230; Graf Hue de Grais: Handbuch der Verfassung und Verwaltung in Preussen und dem Deutschen Reiche $(1895,10$. Aufl.) s. 338, 340; LASH Abt 320 Apenrade nr. 31; Aabenraa frimenigheds arkiv: Sager vedr. bygningen af frimenighedskirken 1903.

59. LASH Abt 320 Apenrade nr. 31.

60. Frede Nielsen: Fra Udmark til Forpost (1938) s. 13f., 25ff.; Aab By 1864-1920 II-9-18: Das Gewerkschaftskartell.

61. Illing: Handbuch für Preussische Verwaltungsbeamte, im Dienste des Staates, der Kommunalverbände, der Korporationen und für Geschäftsleute (1898, 7. Aufl. bearbeitet von Georg Kautz) s. $824 \mathrm{ff}$. spec. lovens $\$ 4$.

62. Som foregående note; Haandbog i det Nordslesvigske Spørgsmaal s. 542ff., hvor H.P.Hanssen redegør for, hvordan forsamlings- og foreningsretten fortolkedes i Nordslesvig; Graf Hue de Grais anf. arb. s. $312 f$. har en mere positiv fremstilling af forenings- og forsamlingsretten $i$ Preussen.

63. Gewerkschaftskartells arkiv, Aabenraa: Forhandlingsprotokol 190113.

64. Entscheidungen des Königlich Preussischen Oberverwaltungsgerichts Bd. 35 (1900) note s. 440f.

65. Gewerkschaftskartells arkiv, Aabenraa: Forhandlingsprotokol 1901-13; Haandbog i det Nordslesvigske Spørgsmaals Historie s. 522 .

66. Entscheidungen des Königlich Preussichen Oberverwaltungsgerichts (1902) s. 426ff.

67. Sagens forløb ses af: Aab by 1864-1920 II-9-18; Gewerkschaftskartells arkiv, Aabenraa: Forhandlingsprotokol 1901-13.

68. Jahrbuch für Entscheidungen des Kammergerichts in Sachen der nichtstreitigen Gerichtsbarkeit und in Strafsachen. Udg. af R. Johow (1900) Bd. 19 s. 295f.

69. Aab by 1864-1920 II-21-2: Die Herberge zur Heimat in Apenrade, spc. skr. 22/2 1894; generelt om herbergerne Zur Heimat, se von Bitter: Handbuch der preussischen Verwaltung Bd. I s. 811.

70. Aab by 1864-1920 II-21-6: Wirtschaftsbetrieb des Herbergswirts Johann Luppi 1883-1906.

71. Aab kr. Verwaltungsstreitsache des Tischlers Hans Christian Erichsen ... wegen Versagung der Erlaubnis der Herbergswirtschaft in Apenrade 1902.

72. Aab kr. Verwaltungsstreitsache des Tischlers Robert Heinrich Luppi ... wegen Versagung der Erlaubnis zum Betriebe der Herbergswirtschaft in Apenrade 1903; Aab by 1864-1920 II-21-6.

73. Hele fremstillingen bygger på Aab ldr $R$ spec 29: Wahl des Zigarrenhändlers Nis Toft ...; Lothar Blatt anf. arb. s. 88f. opfatter det fejlagtigt som en konflikt med de dansksindede.

74. LASH Abt 320 Apenrade nr. 18: Dänischer Staatsangehöriger Toft aus Apenrade.

75. Aab kr. Verband der deutschen gemeinnützigen und unparteiischen Rechtsauskunftsstellen 1910-17. 
76. Aabenraa bys sygekasses arkiv: Protokoll-Buch 1910-22, sarlig møde 12/5 1911 .

77. Se historien om landrådens bil i H.P. Hanssen: Et Tilbageblik IV 1912-1914 (1934) s. 121.

78. LASH Abt 320 Apenrade nr. 24 hft 2, skr. af 6/7 1910.

79. Aab ldr. A spec 2 hft 4 1902-10.

80. Lothar Blatt anf. arb. s. 99.

81. Se også eksempler i LASH Abt 320 Apenrade nr. 61: Bürgermeister Rickmers und Schreck.

82. LASH Abt 320 Apenrade nr. 72: Dänenpolitik, Niederlassungen, Ausweisungen.

83. Formålet var $i k k e$ at finde vand $i$ det tropiske Kamerun, som anført af Sievers i SchleswigHolsteinisches Biographisches Lexikon Bd. 1 s. 275.

84a.Merseburg. Inn. Min. Abt. IA, et sted inden for sekt. 20-34. Venligst oplyst af fhv. landsarkivar Peter Kr. Iversen.

84. Aab ldr A spec 2, hft 4 1902-10.

85. Aab ldr A spec 2 ... hft 5 1911-18.

86. LASH Abt $301 \mathrm{nr} 222$ i Aab ldr. A spec 3 Anstellung des Kreis-Secretairs 1879-1915, skr. 1/8 1913 giver overpræsidentens svar til von Uslar, at han støttede regeringspræsidenten.

87. H.P. Hanssen: Et Tilbageblik IV 1912-1914 (1934) s. 123.

88. Sievers, 1964 s. 43. 